\title{
Internet Video Culture in China
}

Examining Internet culture in the People's Republic of China, Taiwan, Hong Kong, and the US, this book analyzes videos which entertain both English and Chinese-speaking viewers to gain a better understanding of cultural similarities and differences.

Each of the chapters in the volume studies streaming videos from YouTube and its Chinese counterparts, Todou and Youku, with the book using a combination of interpretative analysis of content, commentary, and ethnographic interviews. Employing a diverse range of examples, from Michael Jackson musical mash-ups of Cultural Revolution visuals, to short clips of Hitler ranting about twenty-first century issues with Chinese subtitles, this book goes on to explore the ways in which traditional beliefs regarding gender, romance, religion, and politics intersect. Looking at how these issues have changed over the years in response to new technologies and political economies, it also demonstrates how they engage in regional, transnational, and global dialogues.

Comparing and incorporating the production of videos with traditional media, such as television and cinema, Internet Video Culture in China will be useful to students and scholars of Internet and digital anthropology, as well as Cultural Studies and Chinese Studies more generally.

Marc L. Moskowitz is a Professor in the Department of Anthropology at the University of South Carolina, USA. 


\section{Routledge Contemporary China Series}

195 Western Bankers in China

Institutional Change and Corporate Governance

Jane Nolan

196 Xinjiang in the Twenty-First Century

Islam, Ethnicity and Resistance

Michael Dillon

197 China Studies in the Philippines

Intellectual Paths and the Formation of a Field

Edited by Tina S. Clemente and Chih-yu Shih

198 Innovative and Creative Industries in Hong Kong

A Global City in China and Asia

Grace L K Leung

199 Illicit Industries and China's Shadow Economy

Challenges and Prospects for Global Governance and Human Security

Edited Victor Teo and Sungwon Yoon

200 Re-engineering Affordable Care Policy in China

Is Marketization a Solution?

Peter Nan-shong Lee

201 The Land Question in China

Agrarian Capitalism, Industrious Revolution, and East Asian Development Shaohua Zhan

202 Radio and Social Transformation in China

Wei Lei

203 Internet Video Culture in China

YouTube, Youku, and the Space in Between

Marc L. Moskowitz 


\title{
Internet Video Culture in China \\ YouTube, Youku, and the Space in Between
}

\author{
Marc L. Moskowitz
}

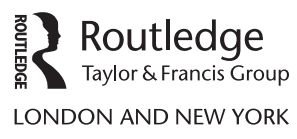


First published 2019

by Routledge

2 Park Square, Milton Park, Abingdon, Oxon OX14 4RN

and by Routledge

52 Vanderbilt Avenue, New York, NY 10017

Routledge is an imprint of the Taylor \& Francis Group, an informa business

(C) 2019 Marc L. Moskowitz

The right of Marc L. Moskowitz to be identified as author of this work has been asserted by him in accordance with sections 77 and 78 of the Copyright, Designs and Patents Act 1988.

All rights reserved. No part of this book may be reprinted or reproduced or utilized in any form or by any electronic, mechanical, or other means, now known or hereafter invented, including photocopying and recording, or in any information storage or retrieval system, without permission in writing from the publishers.

Trademark notice: Product or corporate names may be trademarks or registered trademarks, and are used only for identification and explanation without intent to infringe.

British Library Cataloguing-in-Publication Data

A catalogue record for this book is available from the British Library

Library of Congress Cataloging-in-Publication Data

A catalog record has been requested for this book

ISBN: 978-0-367-20167-8 (hbk)

ISBN: 978-0-429-25991-3 (ebk)

Typeset in Times New Roman

by Wearset Ltd, Boldon, Tyne and Wear 
For Shuenn-Der Yu 



\section{Contents}

List of figures viii

Preface: life in the fifth dimension ix

Acknowledgments xi

1 Introduction: new technologies and the interface between local and global cultures 1

2 Mao mash-ups in the YouTube age 31

3 "Hitler hates the iPad" and other sundry tales:

revisualizing history and culture in the YouTube age 54

4 Is Spock Jewish, gay, or a high-school cheerleader?

Star Trek, YouTube, and nostalgic negotiation of the future

5 Seeing sound: a musical, its YouTube trailers, and Hong Kong's cultural convergence

6 Taiwan's Next Animation Studio battles Conan O'Brien: 3-D animation, the Uncanny Valley, and cross-cultural perceptions

Glossary

Index 


\section{Figures}

2.1 This is a YouTube mash-up that combines visual footage from a 1976 Chinese musical performance entitled The Long March Cycle with Michael Jackson's song Beat It

2.2 This is a second YouTube mash-up combining visual footage from The Long March Cycle

2.3 An 80s electric guitar Rock riff seems to be played on an erhu

4.1 NTU Sci-Fi club in Taiwan. Chunpeng, Lawrence, Tyler, Max, and the author

4.2 NTU Sci-Fi club in Taiwan's Facebook Page

6.1 Next Animation Studio's video of Conan O'Brien was aired on The Conan O'Brien Show in a playful visual conversation between the television show and Next Animation Studio's news outlet which specializes in 3-D news videos 


\section{Preface}

\section{Life in the fifth dimension}

If time can be said to be the fourth dimension, then the Internet must be our fifth. It transcends temporal and geographic space in unfathomable ways. The fact that someone can post a video in Beijing that is seen in Charleston seconds later places Internet-related cultural sharing in a class of its own. Its immediacy across the globe forcefully demonstrates David Harvey's concept of "time-space compression" (Harvey 1990), yet the speed of the ensuing cultural transformation makes a true understanding of this phenomenon a daunting task indeed.

We live in one of the most significant eras in human history-when the birth of computers made way for the Internet age and everything that accompanied it. This ranges from cell phones to robotic trips to Mars; from medical marvels that would have seemed like the stuff of dreams a decade earlier, to a level of surveillance that is reminiscent of a dystopian science fiction novel.

Historically, understanding comes from unexpected places that are often seemingly insignificant and mundane at the time. A casual stroll in an area of Africa known as the Laetoli, created footsteps in volcanic ash that, almost four million years later, became one of the most significant archeological finds in history. In the first part of the nineteenth century, a fragment of a 196 BC royal decree etched in stone, presumably but one of many, became the key to understanding Egyptian hieroglyphics. ${ }^{1}$ Who is to say what historians of the future will make of our YouTube videos? What curious misinterpretations will they create? Indeed, even looking at them today, if we explore the cross-cultural sharing of videos, we see an array of nuanced and often contradictory interpretations.

A few hours on the Internet seems like a marvelous science fiction novel for those of us born in the middle of the twentieth century. Our visual culture is a particularly vivid view into our social subconscious. Cinema has transformed vampires from a heavenly curse into a medical disease. Apocalyptic scenarios are linked with viral infection rather than nuclear Armageddon.

This digitally imbued world that we find ourselves in is having a profound influence on human interaction. Students go an entire semester without talking to anyone else in their class, preferring instead to text with already familiar friends on cell phones and laptops. Selfies are no doubt at least in part an outcrop of this new shyness in that we are no longer comfortable asking a stranger to take a picture for us. 


\section{Preface}

While I hope that this book may lend insight into the contemporary moment, I feel an unusual certainty that the work of our era will be read in the future as a way to gain insight into what it must have been like to live through this historically unique transition. So let me tell you, reader of the future, in unambiguous terms. It is astounding, exciting, often a bit daunting, but on a day-to-day basis our lives are often mundane and uneventful. For the most part we are paying bills and falling in love and eating good food when we can. We are worried about our families and our finances and our health. New technologies seem like toys - marvels of pleasure that are somehow unnecessary until we have gotten used to them. Then we can't imagine how we ever lived without them. Our imaginations and creative expressions are increasingly inseparable from cyber pathways, whether in the form of Facebook, reading e-books, or the remarkably social individual expression in YouTube videos. These videos reflect us, they shape us, they are a visual testament to the birth of the digital age - life in the fifth dimension.

\section{Note}

1 I refer, of course, to the Rosetta Stone.

\section{Reference}

Harvey, David. 1990. The Condition of Postmodernity: An Enquiry into the Origins of Cultural Change. Malden, MA: Blackwell. 


\section{Acknowledgments}

This is my second time working with Senior Editor Stephanie Rogers at Routledge. Her sheer efficiency, enthusiasm, and good sense continue to serve as an inspiration. Thanks also to Georgina Bishop, Senior Editorial Assistant at Routledge, who helped to guide me through the process of getting this book published, and to Jennifer Hinchliffe for her excellent editorial suggestions. Several others also deserve mention here, in that their insights and encouragement were the fuel that kept me going during the endurance contest known as book writing. This includes Joseph R. Allen, Shawn Bender, Beng-huat Chua, Millie Creighton, Jeroen de Kloet, Sharon DeWitte, Guo Jie, Jennifer Neighbors, David Schak, Krista Van Fleit, and Emma Waugh. David K. Jordan, my dissertation advisor in the previous millennium, still continues to allow me to inflict my rough drafts on him. As such, he deserves special thanks for his thoughtful comments, as well as his remarkable stamina and pain threshold, over these many years.

Without Arey Huei-jyun Jhang's help, this book would not have been possible. She provided invaluable linguistic advice when I encountered slang from Hong Kong, Shanghai, or Taipei. More importantly, as my best friend and life partner, she continues to be unwaveringly supportive of this strange career of mine. She demonstrated a near saintly patience on all of those sunny weekends that I chose to sit in a dark room and type and for this I will always be grateful.

Chapter 2 is a revised version of a 2015 article entitled, "From Mao Zedong to Michael Jackson: Revisualizing Culture and History in the YouTube Age." China Information 290: 309-332.

An earlier version of Chapter 6 first appeared in a 2014 article entitled, "Seeing Sound: Perhaps Love, YouTube, and Hong Kong's Cultural Convergence." Visual Anthropology 27: 149-165. 



\section{Introduction}

\section{New technologies and the interface between local and global cultures}

Over one billion individuals visit YouTube each month and 70 percent of its traffic originates from outside of the United States (YouTube statistics n.d.). Yet, surprisingly little scholarship focusing on YouTube or the Internet addresses these new techno-cultures beyond the West. The fact that videos and viewers from different countries are in dialogue with each other is an even more neglected area of study. As we will see in the following pages, even the US-based YouTube server includes a plethora of videos that are posted with a Chinesespeaking viewership in mind. Frequently, people from several different geographical regions post commentary to a single site. At times this results in international sharing, at other times they coexist without interaction-safe behind the Tower of Babel. In many of the videos and posted commentaries that I will present, it is clear that the English speaker is conceptually on the periphery of these spheres.

Worldwide, people watch over one billion YouTube videos a day (Strangelove 2010: 4). In six months, it therefore produces more hours of visual media than the television stations $\mathrm{ABC}$, CBS, NBC combined, for their sixty years of broadcasting, had they each been broadcasting twenty-four hours a day, every day of the week (Wesch 2008). Taken another way, twenty hours of video are uploaded every minute, which is an equivalent viewing time to 114,400 new full-length movies (Strangelove 2010: 10).

YouTube is also increasingly part of global culture. In 2006, 70 percent of its viewers were from the United States; two years later, Americans only accounted for 30 percent of viewers (Strangelove 2010: 11). Clearly, this does not represent shrinking numbers of people accessing YouTube in the US but, rather, an increasing access and awareness of the venue in other areas of the world. Given that approximately 79 percent of YouTube content is user-generated (Strangelove 2010: 10) we can see that we have truly entered a new era of cross-cultural creation and communication. Seeking a better understanding of the multiplicities of Chinese Internet cultures, and the conversation between English and Chinesespeaking fan-created domains, is an important next step in expanding our knowledge of these new techno-cultural formations. 


\section{Introduction}

\section{Anthropology in the Internet age}

As I suggested in the Preface, the speed and scope of the Internet have arguably introduced us to life in the fifth dimension. YouTube and its international counterparts are some of the most memorable and influential aspects of the Internet age. This world of cross-cultural visual dialogues, in which amateur creations exist side by side with million-dollar productions, allows us to laugh and to cry, to share and to rethink the world around us, and sometimes just to relax for a few minutes at the end of a weary day.

Having had the fortune to be alive at the birth of the digital age, many scholars are excited, perplexed, and a tad overwhelmed by the daunting task of bringing anthropological query to this new medium. In informal conversations I have found that a surprising number of anthropologists are skeptical about whether or not studies on YouTube, and the Internet as a whole, can truly be called anthropological. This dismissal of the modern is hardly limited to a mistrust of digital anthropology. Media Anthropology has long been confronted with skepticism. Visual anthropology has also had to justify its endeavors to the larger anthropological community. As a discipline, anthropology has arguably always had a stubbornly traditionalist streak, with an impulse to force culture into a stasis that reveals an inherent mistrust of global trends, such as the consumption of international cuisine, sartorial choices, and other forms of popular culture. Indigenous choices to use new technologies are conceptualized as a betrayal of their culture; a corrupting influence that "we" have had on "them" (Alemán 2012: 148-150). Not that many years ago I was speaking with an anthropologist in Taiwan whose colleagues told him that his work was not "real" anthropology because he studied people in urban settings. Then and now this seemed to be the tail wagging the dog. Should our goal be to adhere to disciplinary standards, or might it be better to adapt our strategies to fit new environments in order to learn more about the world that we actually live in?

Anthropological theorists have called into question place-based ethnology, pointing out the fluidity of local and globalizing influences (Appadurai 1996; A. Ong 1999). These theoretical models serve as important reminders for those who wish to explore digital culture who are confronted with more traditionalist assertions that prioritize place-based ethnographies (Allison 2012; Cool 2012; Whitehead and Wesch 2012). YouTube is particularly ripe for an analysis of anthropological questions of the day, including issues of identity, invented cultures and cultural imagination, globalism, and localization. To neglect this does a disservice to our field.

Anthropologists' reluctance to engage with mass media has resulted in other disciplines' appropriation of the field in conducting work that they label as "ethnographic" (Coman and Rothenbuhler 2005: 13). Mihai Coman and Eric Rothenbuhler make a call for what they see as the core anthropological focus of media studies. They express the hope that anthropologists adopt traditional methodologies to new media while keeping traditions of thick description and 
explaining the meaning and contexts of behavior in relation to larger social processes (Coman and Rothenbuhler 2005: 2).

Participant observation has long been a cornerstone of anthropological methodology and, for many, this is what distinguishes anthropology from other disciplines. Yet, if we define anthropology by its methodology, does that mean that anthropologists have propriety rights to participant observation? Does thick description belong to novelists or anthropologists, and what is served by trying to stake one's claim in this fashion? How are we to understand new cultural formations if we doggedly clutch at methodologies and theoretical constructs that predate our techno-cultural Renaissance?

Many anthropologists conducting Internet studies have attempted to hold onto traditional anthropological theory and practice when exploring this brave new world. They have practiced participant observation online and many have prioritized the Internet's political effects or sense of community. This has taught us much, but a good deal has been overlooked in the process. Anthropologists working on YouTube, and the Internet more broadly, are also confronted with the question of how we are to study cultural manifestations when their creators make no claims to being a community (although they clearly thrive on social interaction in the form of sharing videos and posting commentary). Patricia Lange suggests that YouTube viewers do not form a community as such but, rather, that they should be seen as sharing videos of affiliation (Lange 2008). Though she problematizes what community might mean in such a setting, she emphasizes that such videos "encourage feelings of connectedness, closeness or friendship" (Lange 2008: 77). If we broaden the discussion to include other cultures, community might be seen as linguistic or cultural proximity. As we will see in the following chapters, at times this divides along regional lines, while in other instances it transcends those very same boundaries.

Internet videos would seem to represent less of a community than shared, if always contested, understandings and appreciations. This focus allows us to examine language and visual narrative, as well as culturally bound knowledge and assumptions of what is and is not funny or appropriate. Here we can look at anthropological work in other spheres to gain inspiration. Some of the best work on visual anthropology includes little to no interviews with the viewers. The same standard has not been held to Internet studies. Those engaging in analysis of the media as a cultural text face the danger of being accused of abandoning anthropology for cultural studies. Jan Fernback posits that anthropology has much to offer in studying the virtual world, in that it is here that "the place of the individual within the collective and the power struggle ... unfolds and boundaries are renegotiated, broken, and formed anew" (Fernback 1997: 53).

Linguistic anthropologists have led the way in anthropological explorations of the effects of new technologies on culture. They have broadened anthropological inquiry to include a discussion of textuality in new cyber discourses ranging from MSN to cell phones. ${ }^{1}$ Other linguistic anthropologists have explored the ways that new technologies have profoundly transformed our sociality. ${ }^{2}$ Tom Boellstorf's work on Second Life (2008), for example, makes us rethink our 


\section{Introduction}

assumptions about what defines human interaction, and what makes a community. He argues that online lives must be taken as seriously as offline communities as viable cultures of their own (Boellstorff 2008; Boellstorff et al. 2012).

Another challenge of studying digital worlds extends to the problems of fieldwork on popular culture as a whole. How does one explore cultural imagination when those interviewed have little to say beyond "I like it" or "It's funny." Do we discard what we cannot quantify, though we know it to be an important part of many people's lives, and therefore an integral aspect to cultural formation? Because anthropologists often spend years in their country of research, how do we model knowledge of that culture from experiences that predate research on a particular subject? If we restrict our research to either online or offline worlds, what is lost in the process? If we try to do both, do we sacrifice depth for breadth? Anthropological methodologies have always left us fairly limited in time and scale in that we tend to interview dozens of people in one locale rather than conducting surveys with thousands across a nation. This has made the analysis of cross-cultural dialogues in this context particularly daunting.

The first scholastic books to come out on YouTube were in Cultural Studies (see Burgess and Green 2009a; Snickars and Vonderau 2009). These works include several important insights but they are far more invested in the political and economic significance of YouTube than in exploring cultural transformation in the anthropological sense. In anthropology, Patricia Lange and Michael Wesch made some of the first steps in using an anthropological lens to investigate YouTube culture. Wesch provides cultural analysis of genres of YouTube videos as new modes of communication by uploading videos on YouTube that are lectures on the topic of the anthropology of YouTube $(2007,2008)$. As with most of the scholarship that I have outlined here, these anthropological works focus on Western culture.

Patricia Lange's work on YouTube use among California high-school students (2008) primarily examines offline lives, emphasizing the importance of the act of producing videos rather than the content that is created. In doing so she provides a rich ethnography for their offline interactions, but she provides less of a sense for what was at stake in their online lives. Several other scholars have also explored digital culture with great success (see Boellstorff 2008; Coleman 2014; Jones 1998; Nardi 2010; Taylor 2006), but these studies are also evidence that in dealing with such a broad a topic, one must make hard choices about what to include and what to ignore. It is hardly surprising that the most influential English-language anthropological works on digital culture focus on America, in that exploring the Internet already presents such an intimidating complexity of issues.

The assumption that offline interactions are more "real" than those that take place online is also problematic (Boellstorff 2008; Boellstorff 2016). As Daniel Miller and Don Slater suggest, "In fact this focus on virtuality or separateness as the defining feature of the Internet may well have less to do with the characteristics of the Internet and more to do with the needs of these various intellectual 
projects" (Miller and Slater 2000: 5). Offline and online lives converge in important ways. One can maintain friendships in spite of moving to a new location. It is not a stretch to think of academia as a community, though for the most part our face-to-face interactions are limited to a handful of conferences a year and the interactions left to us on Facebook and Twitter.

We must also rethink offline communities. Internet crimes such as pornography, copyright violation, or revealing national secrets have had very real effects on offline lives. Gabriella Coleman's sensitive account of the hacktivists group Anonymous relates the emotional hardships and prison time that results from illegal online activities (Coleman 2014). Julian Assange, the founder of Wikileaks, and Edward Snowden, who released a breathtaking amount of government documents, have become symbols of heroism to many. But they also serve as a warning for just how dramatically one's life can be destroyed as a result. Is a family sitting in a room together silently watching television more or less engaged with each other than a group of friends chatting online as they play World of Warcraft? With the interactive game Pokémon go, where is the distinction between online and offline?

Critiques concerning the flexibility of online identities overlook how malleable our presented personas are in offline contexts; the very different ways that we act with friends, parents, or police, for example. There are, of course, sensory experiences that we are deprived of in our online lives, such as olfactory sensations and the feel of an embrace. Another distinctive aspect of offline life is when we are forced to interact when we do not want to - strained conversations with family members and friends that lead to an emotional depth that one does not develop if one can merely sign off when in a bad mood.

Many people look back on the idea of community with a nostalgic sense of loss but forget the ruthless mechanisms of power that are imposed on those who do not fit society's image of itself. Others feel that online life can be more sincere and meaningful than offline interactions in which one's identity has been defined by accidents of birth, or by social contexts beyond their control. Some people might turn to the Internet to leave their wheelchair or terminal illness behind, if only for a moment (Graffam 2012: 142). For gay high-school students in conservative small towns, online companions provide a lifeline that includes far more honest friendships than the hidden and fearful closeted identities of their offline lives. These students might share physical space with classmates but that can hardly be said to be more authentic interaction.

\section{Internet videos as modern mythology}

Henry Jenkins reminds us that YouTube was not born in a vacuum but, rather, that its quick growth was largely due to long-standing participatory cultures (Jenkins 2009: 109). Where would YouTube's current manifestation be without the established enculturation of MTV or television commercials which inform much of our understanding about what short videos should look like (Jenkins 


\section{Introduction}

2009)? Similarly, the Internet age offers ease, speed, anonymity and geographical scope that humanity has not experienced before, but this interaction draws on preexisting cultural norms. For a century before the Internet, many people experienced the profound emotional closeness of relationships that were experienced through the postal service. Loves and friendships blossomed without faceto-face interactions in relationships, such as those between pen pals and of spouses separated by the necessities of war.

George Marcus sees the Internet as a cultural extension of ancient narrative forms (Marcus 2012). He points out that anthropology has a long tradition of exploring cultures through their abstract imagination, including mythology and Shamanistic worldviews (Marcus 2012: xv-xvii). Jack Lule makes a similar point when he states, "We should appreciate that in our modern, high-tech, online world, we find stories and practices that date back to tribal times" (Lule 2005: 109). Other scholars have also suggested that mass media, including fiction and the news, can be seen as the mythology of the modern age. ${ }^{3}$ Although each of these studies have complex arguments in their own right, certain themes do emerge. This includes the idea that news media employ age-old archetypes of good and evil, hero and villain in their portrayals (Coman and Rothenbuhler 2005: 7; Lule 2005: 102-103), that ritual speech adds to a sense of order in chaos (Coman 2005: 46; Coman and Rothenbuhler 2005: 9), and that our stories reflect and shape our cultural values (Coman and Rothenbuhler 2005: 9; Lule 2005). Like mythology, this appeals to the viewer less as rational systems than as symbolic frameworks (Coman 2005: 46; Coman and Rothenbuhler 2005: 9).

In choosing to attend to the symbols and meanings of cyber culture, perhaps we are returning to even older forms of anthropology when the focus was on symbolic systems of understanding the world around us (Coman 2005: 46; Coman and Rothenbuhler 2005: 9). When Roland Barthes opined that "Myth is not defined by the object of its message, but by the way in which it utters this message" (Barthes 1972: 109) it is hard not to think of Marshall McLuhan's famous insight that in Mass Media "the medium is the message" (1973). Both statements seem strikingly fitting for studies of digital expression. Our innate ability to create and interpret the symbolic in our online lives, is clearly not as dramatically different as one might first assume (Tufekci 2012: 34).

Early Frankfurt School explorations of popular culture cast a wary eye on the ways that new media can discipline a populace and the manner in which it readies them for their alienated place in the Weberian conformity of industrial social structure (see Adorno 2000; Benjamin 1969). Yet fans are active participants who create their own narratives and thereby transcend the original formations of that media (Allen 1983; Dyer 2000; Jenkins 2008). In addition to situating their analysis in one imagined monolithic popular culture industry, the Frankfurt School also assumed a remarkably unified audience culture. Popular culture industries are engaged in symbiotic relationships (the music and movie industries, for example) but they should not be taken to be unified in their goals or production. Nor should we assume that viewers in Beijing, Atlanta, and Taipei derive the same meanings from what they see. 
Walter Benjamin ended his treatise on mechanical reproduction by making a call for art that is politicized as a means of rejecting what he saw to be an entertainment of distraction (Benjamin 1969: 242). Yet the videos I have presented here highlight the fact that the seemingly apolitical nature of popular culture can be far more transformative than a more overt dogmatic propaganda piece could ever be. Hollywood films provide a fecund ground for examining the ways in which popular culture can provide double readings. The film Die Hard (McTiernan 1988) is not just about an unlikely hero that does battle with unscrupulous foes. It is also a metaphor for endurance that audience members can relate to their own lives. It is resonant and cathartic because the hero is beaten and punched, made to run barefoot through broken glass and then to use his torn feet to kick in another barrier in the form of a glass window. Every time he stands up after being beaten down it reminds the audience of their own travails - of enduring jobs that they hate, of making ends meet in the face of the ever-expanding financial needs of their children. The movie Memento (Nolan 2000) is another example. On one level it is a welcome distraction from the problems of everyday life. Yet it is also a profoundly thoughtful film about the nature of memory, identity, and manhood. The self-constructed hero turns out to be culpable, willfully creating his own fantasy of self and other while neatly obfuscating his complicity in the tragic events that ensue. As with Die Hard, Memento is cathartic in the sense that the villain is vanquished in the end, but also because one recognizes the traps of masculinity that the film explores. It suggests that culturally viable expressions of desire and love are hampered by the socially acceptable repertoire of men's self-expression. In these films, and many others, the message is far more subtle, and powerful, than a pedantic film on the abuse of women or the trappings, or traps, of masculinity.

Media Anthropology has much to offer in conceptualizing studies of digital culture. Anthropological explorations of mass media have provided valuable insights into the ways that television, for example, has given us a model to live our lives. Lila Abu-Lughod suggests that Egyptian television melodramas become a "technology for the production of new kinds of selves" (Abu-Lughod 2002: 116). They do so, she argues, by "popularizing a distinctive configuration of narrative, emotion, and subjectivity" (Abu-Lughod 2002: 116). She demonstrates the ways that people might frame their own life stories as if they were heroines in their own melodramas (Abu-Lughod 2002: 124).

Purnima Mankekar suggests that Indian television provides viewers with easily understood models of thought and behavior, such as religious belief (Mankekar 2002: 136) and gendered behavior that viewers can emulate in their real lives (138-139). Mankekar highlights the religious concept of darshan (seeing the divine) in Hinduism as taking on new but very literal meaning as one watches a television show about Lord Rama (Mankekar 2002: 137). She goes on to show the very different ways that Muslims and Hindus respond to shows that draw on their religious and ethnic backgrounds, as well as class differences in audience reception (Mankekar 2002: 140-143). 


\section{Introduction}

Similarly, the online videos that I have examined here assist English and Chinese-speaking viewers in an effort to engage with international dialogues that at times confirm, and at other moments contradict, their traditional worldviews in surprisingly profound ways. The somber memorializing of state-sanctioned propaganda is challenged by inventive playfulness that has arguably not been seen before on such a grand scale.

\section{Clash of the Titans: when different mythologies collide}

The above-mentioned notion that mass media is today's mythology is an important one. Yet we should remember that this is a highly contested domain. Differentiated readings interface with a viewer's gender, ethnicity, economic class background, and generational views. As Mark Peterson reminds us, intertextuality is not only consumption or the creation of texts, but a production that people enact and emulate (Peterson 2005: 130). That one can bond with strangers and friends by citing famous lines from movies and demonstrating knowledge of popular shows and music is another central part of socialization (Peterson 2005: 130). This serves as an important reminder of Michel de Certeau's point that "everyday life invents itself by poaching in countless ways on the property of others" (1984: xii).

Anthropologists have drawn on Benedict Anderson's work on imagined communities (2006) to explore the ways that mass media helps to strengthen notions of national identity as a distinctive social, political, religious, and/or ethnic space (see Hamilton 2002: 152-153; Mankekar 2002: 145; M. Yang 2002). At other times that same media is seen as a threat to national unity (see Hamilton 2002: 156; Mankekar 2002: 146; A. Ong 1999; M. Yang 2002). Television, for example, can be used to reconceptualize one's place in the global order in relation to colonial histories in juxtaposition with the contemporary global political economy (Larkin 2002; Mandel 2002; Wilk 2002). Mass media can also help to solidify diasporic viewers' affinity for their imagined homeland (Schein 2002). Ann Hamilton notes that in Thailand, media often ushers in Western worldviews through foreign cinema but that many continue to prefer Chinese or Thai productions and that their choice to do so is considered to be an act of cultural loyalty (Hamilton 2002: 158). At the same moment, "authentic Thai" cinema also carries associations of being dull or banal as opposed to the more glamorous visuality of Western media and its exotic-other actors (Hamilton 2002: 160). As Faye Ginsburg points out, mediascapes "increasingly escape the control of national political structures and economies, rearranging, in the process, the ways in which cultural formations are spatialized and imagined" (Ginsburg 2005: 21). New technologies are thereby eroding national boundaries in favor of crosscultural flows (Appadurai 1996; A. Ong 1999).

Digital culture creates mythologies that are contested in different regions. A great many people are in dialogue with often contradictory values and understandings that are born of several cultures. Chinese familiarity with popular culture from Japan, South Korea, Taiwan, and the United States is but one 
example. Who is deemed to be the hero and villain of a tale of course varies according to the storyteller. Northern Vietnamese and American depictions of the Vietnam War have very dramatic differences, for instance. Conceptual frameworks revolving around heroic deeds is another example. Rebellion against authority is a much more pervasive theme in US films than in their Chinese counterparts. Obedience to one's parents is framed as heroic in traditional Chinese tales and contemporary cinema to a degree that most people in the US would find surprising.

There is a complex cultural interplay that takes place when visual tales in movies, television, corporate-, and fan-created YouTube videos, are shared between cultures. Internet videos assist us in rethinking our conceptual categories and worldviews. In doing so they help us to do battle with historical phantasms ranging from the Holocaust to the Cultural Revolution, to abuses of power in modern capitalist oligarchies. These moments in history and the contemporary moment are too horrible to truly comprehend. They are very real tragedies, it is true, but they are also reinforced and given life by our more somber memorializing. The videos that I have presented here remind us of our humanity in spite of our knowledge that, in a very Hegelian sense, we are at war with ourselves - caught between a Cartesian mind/body duality that seemingly juxtaposes our civilized forms with our savage impulses. These videos can be seen to free us from the conceptual frameworks that might otherwise inform, yet also encage us. They enact an important remembrance by disarming atrocities through playful irreverence. They undermine current regimes and contemporary mythologies that would have us engage with anything of import with a somber joyless reverence. In laughing at our tragedies and combining disparate elements from the world around us, we remember, reinvent, and reconceptualize. The past, present, and our most hopeful futures thereby become intertwined with our very best nature - to face the hardships of the world with creative playfulness. In doing so, we gain a mastery of the fleeting and most important moments in our lives.

\section{The Internet and visual dialogues between China and the US}

The advent of the Internet age is leading to dramatic cultural changes, the scope of which has not been seen since the Industrial Revolution, and which arguably exceeds even that momentous moment in time. Donna Haraway's essay questioning whether or not we are all cyborgs (1991), might once have been read as a somewhat ironic feminist critique. Today it seems to be a rhetorical question.

Visual technologies are transforming individual interactions and, more broadly, the social fabric of Chinese-speaking Asia, including Mainland China, Hong Kong, and Taiwan. These new technological milieus feature visual creations in relation to American popular culture as they stand in the forceful tide of globalizing influences. In examining digital culture, the tendency to focus on one language or nationality ignores how porous these boundaries have become. This theoretical embrace of one imagined homogeneous community as a hypothetical 
audience fails to explore the intense interplay of different cultural elements that might contribute to mass-mediated culture arising out of local, transnational, and global dialogues. Hong Kong and Taiwan's visual and musical productions, for example, have long been symbols of border-crossing hybridity. Their visual cultures have had a profound influence throughout East Asia and beyond. As such, they are excellent exploratory points to examine the ways in which transnational production becomes part of a cross-cultural communication with the audience, one that engages with musical and visual images of the past and present, here and there.

There are times when digital culture presents strikingly varied voices even within Chinese-speaking Asia. This evinces both the similarities and the differences between local cultures and individual psyches in Beijing, Hong Kong, and Taipei, for example. It also forces us to confront the ways in which cultural production is shared, co-opted, and reinvented in the exchange between the US and the People's Republic of China (PRC).

Scholarship on the Internet tends to focus on written texts, but it is important to remember that this is also a profoundly visual sphere. Worldwide, in 2010 there were already two to four billion consumer devices that eased the way to amateur video production on cell phones, video cameras, iPads, laptops, and video recording devices (Strangelove 2010: 17). The Internet's visuality includes photography, moving image, and choices made in presenting texts including font, size, and page layout.

Visually oriented forms of popular culture manipulate our awareness of time and place. As we will see in the following chapters, this spans from depictions of Nazi Germany to the Cultural Revolution, and it combines its imagery with music by artists ranging from Michael Jackson to Taiwan's Mandopop star Jay Chou, to the Korean K-pop (Korean pop music) group the Wonder Girls. These videos thereby highlight the idiosyncrasies of current localized political economies and cultural change in relation to transnational and global interrelationship. These sights/sites and sounds are evidence of complex hybrid cultural forms that transform historical hierarchies from traumatic locally bound events to irreverent transnational sharing and rivalries, imitation and resistance. They do so locally and as fairly limited transnational cross-pollination between East Asian nations. They are also markers of a much larger and ever-expanding global participation.

Sinologists have raised several questions regarding the Internet's profound influences on modern Chinese society: How do Internet creations result in changing viewpoints that may be at odds with the government's desires for its citizens (Herold 2011: 9)? How might it help Chinese youth to give voice to their anxiety about the current job market or find their way in such a fiercely competitive society (Szablewicz 2014: 262)? In what ways are digital media helping people to find or express identities that do not align with mainstream visions of what it means to be happy or successful (Szablewicz 2014: 262, 270-271)? As in other regions of the world, the prevalence of smart phones means video evidence is frequently posted online to give lie to these myths. 
In analyzing YouTube videos in both English and Chinese-speaking contexts I believe we can learn more about each culture, and about the fascinating exchange between the two.

This approach ushers in additional questions concerning culturally bound knowledge of history and today's world. Do Hitler parodies, for example, mean the same thing in the English and Chinese-speaking contexts? Does the odd blend of futurism and nostalgia of American conceptions of Star Trek apply to Chinese-speaking viewers, and what does it signify when examining depictions of race, ethnicity, and the expansion of cultural hegemonies? When The Conan O'Brien Show playfully battles the Taiwan-based Hong Kong subsidiary Next Animation Studio with Chinese-language news 3-D animation videos, what are the cultural perceptions of self and other that are enacted? ${ }^{4}$

Part of what is at stake here are the multifaceted ways that Chinese-language mass media from Hong Kong and Taiwan remap Chinese culture by being so central through their popularity, although geographically and politically they are considered to be on the periphery (Moskowitz 2010, 2011; M. Yang 2002). An important part of their popular culture's distinctively local appeal is the ease with which they are in dialogue with each other, with Japanese and South Korean popular culture, and with Mainland China. Paradoxically, it is precisely this transnational hybridity that defines Hong Kong and Taiwan as distinctive cultural spaces.

In the PRC, visual representations are a particularly adept medium for evading China's Internet censorship, which primarily relies on keyword search functions (Szablewicz 2014: 262). In turn, Chinese-speaking cultures are visualized through the lens of popular culture across mass-mediated frameworks. Any discussion of this topic must therefore include visual representation, ways of seeing, and modes of knowing. It is said that a picture tells a 1,000 words, but we sometimes forget to ask how honest that narrative might be. Nothing conveys truth more quickly or emotionally than a well-placed photo, yet nothing lies quite so gracefully under pressure.

\section{China's Internet and the creative appropriation of other cultural imaginaries}

In the year 2000, China had roughly 22.5 million Internet users, accounting for approximately 1.7 percent of its population (Internet World Stats n.d.). By 2014 this number had risen to 420 million, which represented 31.6 percent of its citizens (Internet World Stats n.d.). Although this does not rival the percentages of many other countries, when taking into account China's 1.3 billion people, we are confronted with the fact that there are more Internet users in China than in any other nation in the world.

The PRC's Internet is so focused on local concerns that Guobin Yang has suggested that one can conceptualize it as a distinctive space that might legitimately be spoken of as the "Chinese Internet" rather than just the "Internet in China" (G. Yang 2012: 49). Most Chinese Internet users prefer their anonymity, 


\section{Introduction}

for example, and consider their online identities to be quite separate from their offline identities (Herold 2012: 2, 4-5). This lends to the conception that online activities are just play - a cultural zone in which one does not have to be afraid of consequences for one's actions (Herold 2012: 11).

Perhaps the most infamous aspect of China's Internet is the degree to which the PRC government continues to attempt to control China's flow of information. "The Great Firewall of China" has been used to block international sites as well as censoring anything with politically sensitive keywords such as "Tibet." In truth, these restrictions are not overly difficult to evade. One can purchase a VPN (virtual private network) connection, which tricks firewalls into thinking that a computer is accessing the Internet in locales such as Buenos Aires or Dallas. Ultimately this adds to the expense of accessing the Internet, however, which is already significant for many in China. Also, as in the US, one never really knows the degree of protection that a VPN can buy in hiding one's identity from the State. Even with the options available to gain access to the outside world, approximately 96 percent of Web traffic in China is local (Roberts 2011). This is partially the result of China's Great Firewall, to be sure. Nevertheless, people in China also avoid Internet sites outside of the PRC because of problems that include unusably slow speeds, time outs, and the difficulty of maneuvering with other languages (Herold 2012: 2; Roberts 2011).

Many forget that China's cyber culture also extends across the globe. A significant number of written commentary posted to YouTube videos designed for a Chinese-speaking audience feature simplified Chinese characters, which are used in the PRC. This highlights the fact that the Great Firewall is not as imposing as some might suggest, while also reminding us of the millions of Chineselanguage speakers living in other areas of the world.

In spite of our understandable concern with China's somewhat Orwellian attempts to limit the flow of information, we should remember that English speakers are no strangers to censorship. American mass media features seemingly ubiquitous mechanisms to censor what is shown in relation to nudity and sexuality. US legal regulations concerning copyright violation evince a semireligious faith in the rights of individual creators, though often downplaying the needs of individual consumers who wish to appropriate those products in mash-ups and other forms of fan production. In contrast, China's government cares little for protecting US copyrights. As a result, videos using copyrighted materials are frequently removed from YouTube but remain on the Chinese video server Youku. In the context of China's attempts to control information this is in some sense surprising. It also places accessing pirated copies of films and books, whether online or in other forms, as a potentially moral and liberating act.

The PRC has also been remarkably tolerant of individuals' video rants against the State, though it quickly removes anything that shows flash mobs or other public gatherings from Youku for fear of public unrest. Discussions of censorship in China and the United States necessarily respond to a particular set of cultural values. Viewers' written and verbal commentary on censorship respond in 
equally culturally bound ways that revolve around, and call into question, the value of free speech, democracy, traditions, and global participation.

In spite of its continued efforts to limit the flow of information, the PRC's control of media in the first few decades of its rule stand in stark contrast with Chinese people's relatively abundant access to news today. In 1979, there were only sixty-nine newspapers in all of China (Shirk 2011: 7-9). By 2005 there were over 2,000 newspapers and 9,000 magazines (Shirk 2011: 7-9). Beginning in the late 1980s, the PRC established its first Internet links, although this was exclusively between Chinese universities. In 1994, China's Internet connected to US servers, followed by two years of expansion that created links to Japan, Southeast Asia, and Russia (Herold 2011: 1). It was only in 1997 that private citizens were allowed to use the Internet (Herold 2011: 1). The PRC continues to use a relatively heavy hand in its efforts at censorship, however. As but two examples, it continues to attempt to control the flow of information by attempting to force Google to censor certain politically charged topics, which resulted in their leaving the country, and it prohibits foreign journalists from posting articles to Chinese-language sites. China's leader Xi Jinping seems intent on strengthening government control through increasingly heavy-handed mechanisms such as censorship and linking credit scores with compliance to State doctrine.

The PRC's efforts to control public opinion on the Internet are also exemplified by the 50 Cent Army (wu mao dang). This is a colloquial term that refers to the government's practice of employing individuals to post comments online that align with the State's political opinions. For this service, they are provided with a commission of 50 cents RMB (wu mao) for each comment that they post. ${ }^{5}$ Andrew Jacobs has documented the 50 Cent Army's intrusion into the Western Internet with the example of a Twitter account that claimed to belong to someone named Tom Hugo who posted opinions on Tibet in order to sway global opinion (Jacobs 2014). It was later discovered that Hugo was a PRC-fabricated identity and that his picture was in fact that of a Brazilian model (Jacobs 2014).

One unintended consequence of the 50 Cent Army is an increasingly cynical public that is wary of any comments that might align with the government's stance. This creates an atmosphere in which someone who sincerely and independently makes a nationalistic comment may be mistrusted as a government plant (Link and Qiang 2013: 91; Shirk 2011: 26-27). This can result in the selfcensorship of people who might otherwise show support for the government because they do not want to be mistaken for the 50 Cent Army (Shirk 2011: 26-27). Whether this is ironic or poetic justice depends on one's political stance. Regardless, it has certainly had a profound influence on people's already heightened level of cynicism in China. The 50 Cent Army has become such a wellknown phenomenon that its meaning now extends to anyone who apologizes for the PRC regime, as when Henry Kissinger praised China's leaders (Link and Qiang 2013: 92).

The government has responded to this widespread cynicism by shifting its strategy. In addition to posting obvious propaganda statements that refute comments that are not approved of by the State, the 50 Cent Army now floods the 


\section{Introduction}

Internet in response to topics that it does not approve of, in the hopes that this will distract readers from the topic (BBC News 2016a). By one estimate, the 50 Cent Army accounts for 488,000 posts a year (BBC News 2016a). This shift from overt propaganda to one of distraction shows the growing sophistication of the PRC in handling mass media. It should not be overlooked that the model for flooding the Internet with tales of distraction was arguably inspired by the US.

Although the PRC has become increasingly savvy about the Internet, public maneuvering on the Internet is not without its ironies. In 2015, China's president Xi Jinping signed up for a Facebook account to promote his trip to the US, in spite of the fact that Facebook is banned in China (S. Yan 2015). The man who is widely credited with creating China's Great Firewall accessed a blocked Internet site with VPN in front of his audience (BBC News 2016b).

Cynicism pervades contemporary Chinese culture and it is the foundation for a good deal of its humor. Cynicism and irony in China are born of the same political and cultural environment, and to some degree they arise from the same set of sentiments. Yet they often work in oppositional ways. Hans Steinmüller suggests that "irony leaves space for interpretation, whereas cynicism closes this space and implies radical criticism, denial or resignation" (Steinmüller 2016: 2). Cynicism and irony define inner and outer circles of like worldviews and moral alliances (Audin 2016: 103; Steinmüller 2016: 2). Cynicism might be seen as the complacency that allows the system to continue. Irony contrasts this as a voice that undermines the State's attempts at maintaining an Orwellian doublespeak.

In China, cynicism is in large part a result of living in a relatively totalitarian society that speaks of socialist revolution even as it embraces an exceptionally corrupt oligarchic capitalism that is reminiscent of the early industrial West. The fact that government officials, businessmen, and gangsters are at times indistinguishable categories does not help. Part of the reason people can mediate so readily between official discourse and the economic realities of contemporary life is that people (cynically) see official discourse as a purely cynical public manipulation that lacks sincerity to begin with (Osburg 2016: 48). In this cultural milieu, officials who speak of bettering society are often thought to be most callously exploiting the system (Osburg 2016: 49).

Judith Audin notes that an anthropological examination of irony also "allows us to move away from normative paradigms and binary oppositions such as cooperation or resistance from Chinese citizens towards the Chinese state" (Audin 2016: 117). In turn, Susanne Brandstädter points out that irony subverts state discourse and that its "tactics confound fundamental political categories, and [...] def[y] categorization by uniting moral and political opposites in one person" (Brandstädter 2016: 123). Irony also forces us to discard our assumption that meaning is bound to authorial intent in that ironic readings can quite easily become the primary meaning for most (Latham 2016: 157).

Louis Althuser outlines the ways that States enforce ideology, not only through top-down control such as the military, police, and prisons, but through ideological state apparatuses such as religion, educational institutions, literature, and mass media (2014). China proves to be fecund ground on which to apply 
this analysis. Yet we should not think of "the State" as one unified body with a coherent set of goals. This would neglect a wide array of political and private entities, as well as the reality that individuals within these systems have their own set of preferences, biases, and agendas.

In spite of the PRC's reputation as a top-down regime, in many ways it is one of the best examples of a political culture that is shaped by popular consensus on the Internet. Jürgen Habermas' notion that a great deal of public policy and popular opinion was formed in informal settings such as clubs and coffee shops has much to offer here (see Habermas 1991). China's Internet can be seen as a modern-day extension of Habermasian theory in action (X. Wu 2007). Nonetheless, the Internet's playfulness also challenges the normative structure of rationalism conceptualized in Habermas' theories of the public sphere (Burgess and Green 2009b: 102; Herold 2011: 11). It simultaneously creates cultural solidarity through shared worldviews and rebels against commonly held notions of a unified discourse or culture.

China's Internet has created a space to expose corrupt officials, individual cases of abuses of power, and scandals that the government has attempted to cover up. This includes train crash mortalities and reckless drivers literally getting away with murder because they are the offspring of the rich and powerful. ${ }^{6}$ One of the reasons Internet uprisings can be so effective is that officials are keenly aware that public scandals can later be used against them if they are caught up in a power struggle, and it makes them easy targets for scapegoating should higher-ups need a sacrificial victim (Link and Qiang 2013: 85).

Censorship and a constant threat of imprisonment are certainly not forgotten by those on the Web, and even instances of more positive change have their limitations. The Internet has shifted China's public attention from large-scale social transformation that might threaten the status quo, to fixing specific problems such as individual cases of corruption and animal abuse (N. Zhang 2014). In a sense, Internet protests still serve the State because in allowing an online space for dissent, it helps the government to keep angry mobs off the streets (Shirk 2011: 7). One could also argue that online protests are less a subversion of authority than a safety valve, something that makes an untenable situation bearable (Herold 2011: 12; H. Li 2011: 85).

It is impossible for the Chinese government to completely limit the flow of information, both within and beyond its borders. China's Internet has provided a new sphere in which users can have a surprising degree of autonomy and room for creative and social exploration. This seems to be nothing less than a newly given space for citizens to explore new identities and to build their own appreciation of the world around them (Clark 2012: 190). Although the Internet has changed the lives of people of all ages, it has had a particularly strong impact in allowing youth culture to emerge in a nation that is primarily controlled by older members of society (Clark 2012: 190).

Paula Voci takes issue with the oft-heard claim that Chinese people are passive users on the Internet in comparison to their Western counterparts (Voci 2010: 118). She points out that this bias stems from the assumption that the 


\section{Introduction}

English-language domain of the Internet is of prime importance (Voci 2010: 118). Speaking in code is but one example of the creativity that saturates China's Internet. Paul Clark provides several examples of this:

5843344521 sounded almost like wo fashi shengshengshi shi wo ai ni: "I pledge generation after generation that I love you." Similarly 7456 stood for qisi wo le: "I'm really fed up." Numbers could also play on foreign languages. For example, 121 (in English, one to one) was a way of saying "I want to speak to you person to person (one to one)." Using "007" meant "I have a special secret I want to share with you," based on the reference to the James Bond films.

$\left(\right.$ Clark 2012: 179) ${ }^{7}$

As with so many aspects of Internet culture, speaking in code draws on the remediation of older traditions. In the 1990s, Taiwan's television programs featured commercials for Straw Hat Pizza which had been savvy enough to choose 5252 (wu er wu er) as part of its telephone number because this sounded like "I am hungry, I am hungry" (wo e wo e). One also frequently saw commercials for "female masseuses" that included 5454 (wu si wu si) in their telephone numbers because it sounded like "I am horny, I am horny" (wo se, wo se). Undoubtably, these traditions date back to far earlier than this.

Speaking in code also becomes a handy way of avoiding censorship on the Internet. The use of the term "grass-mud horse" (caoni ma), for example, is a homonym for the popular insult "fuck your mother." This took on a visual dimension as this newly created mythological being was presented on the Web in the form of stuffed toys, drawings, and a fake children's song. ${ }^{8}$ In 2018 , the PRC government banned all images of Winnie the Pooh because people were circulating pictures of Winnie the Pooh and Tigger, with direct comparisons to the relatively portly Chinese leader Xi Jinping walking side by side with the tall and lean Obama. As with other images circulated on China's Internet, pictures of Winnie the Pooh neatly bypassed the keyword searches of censorship bots. Of course, the government's decision to censor images of Winnie the Pooh only drew attention to the comparison, both in China and in the West.

It is relatively easy to trace the Internet's effects on political unrest, the demand for social justice, or other demonstrable actions or goals. It is far more difficult to examine the ways in which the Internet captures viewers' imaginations and shapes their conceptions of the world. Online satire is an emotional expression that provides us with insights into new cultural views of the digital generation (Gong and Yang 2010: 4). Rather than simply measuring this along political lines, perhaps we should instead see these new values and sensibilities as the more profound and far-reaching set of cultural changes. 


\section{The long reach of the law: political alliances and the shifting Chinese market in East Asia}

In 1988, when I first lived in China, if a Hong Kong film was dubbed into Mandarin Chinese it inevitably featured a Taiwanese accent. Almost immediately after Hong Kong was repatriated to Mainland China in 1997, dubbing switched to the northern Mainland Chinese accents that are associated with China's capital in Beijing. This clearly reflected a change in politics with an eye to who had the power to decide what would, and would not, be screened in the increasingly important PRC market.

Today, Chinese-language news media continues to be geographically distinctive. Taiwan's newspapers are politically aligned with either the pro-Taiwan independence or pro-unification camps. Next Animation Studio Taiwan, a Hong Kong conglomerate subsidiary that I will focus on in Chapter 6, does not take a clear position on Taiwan's independence but it is known for its pro-democracy stance. In Hong Kong this is synonymous with a desire to be free of PRC rule. My interviews at Next Animation Studio Taiwan took place just after the birth of protests for democracy in Hong Kong. At that time, Next Animation Studio was particularly controversial among the ruling elite in the PRC for a longstanding stance on this issue. In response, the PRC government had blocked the Mainland Chinese links of both Next Animation Studio, and its subsidiary news agency The Apple Daily. When I asked Jessica Wu, the International Marketing Manager at Next Animation Studio Taiwan, if they had any problems with PRC censorship she replied:

wU: The Chinese government hates us. Right now, because of the Hong Kong [pro-democracy] march, hackers have been attacking our web site both in Hong Kong and Taiwan. We're pretty sure it's from China. [She laughs.]

MOSKOWITZ: How do you respond to that?

WU: Our IT guys try to make sure our web sites don't go down. But they've been going down more frequently. Because in Hong Kong they also had their vote a week or two ago. Anything they do also affects our operations. ${ }^{9}$

When Wu referred to "their vote" she was referencing widespread protests in Hong Kong because the PRC was providing two candidates to lead Hong Kong, for people in Hong Kong to vote on, rather than allowing them to choose their own candidates. An estimated 600,000 people voted in an unofficial poll about democratic reforms, although the PRC government specifically warned against this. The protesters had to extend the polling for a week because of frequent cyber attacks that most attributed to the PRC. Wu was therefore pointing out not only that Next Animation Studio was an emblem of the pro-democracy movement, but also that it had been swept up in geopolitics that were much larger than itself.

Michael Logan, Next Animation Studio's Director for Content Development, leads its international news division. I also asked Michael Logan about censorship. 
LOGAN: The stuff that we produce is not politically sensitive. Everyone who does media in China knows that there are topics that if you cover them will get you banned. We certainly don't cover those. I mean, my team does because we work on Japan and the US. For the most part we don't do anything that is sensitive. But because of who we are, that content can't get distributed in China. We've tried distributing our international news reports there. We've put it up on Tudou and Youku but it just gets taken down.

MOSKOWITZ: In the United States when something is taken down it often pops up again somewhere else because someone just copies the video and puts it back up. Does that happen with your videos?

LOGAN: People do copy our stuff and upload it to the various Internet servers in China. A fair bit of The Apple Daily [a subsidiary of Next Animation Studio] content in Hong Kong gets ripped off and copied and uploaded. The people that are in China are able to do that and they don't encounter any problems. So, it really depends on who's doing the uploading. If it's anybody within Next Animation Studio trying to upload something they will figure it out pretty quickly. ${ }^{10}$

The culture of re-posting has very different implications, depending on whether one looks at it from an economic or a political perspective. On the one hand, creators of the videos are cut out of the profit-making for their production. On the other, these pirated postings disseminate cutting-edge news and transnational worldviews in China. In China, as well as in other areas of the world, it is easy to overlook the ways in which mainstream media can also be quite subversive.

Mark Peterson reminds us that demonstrating knowledge about popular media is a form of symbolic capital and a core aspect of socialization, "People become performers of texts, and they also become producers of texts, weaving elements from the media they have consumed into new narratives and artifacts that can be displayed to construct particular forms of sociality" (Peterson 2005: 130). In turn, he notes, "Much of this behavior becomes itself the subject of public discourse, as religious leaders, lawyers, educators, psychologists, and others speculate on the moral effects of such intertextual play" (Peterson 2005: 130).

Jean Burgess and Joshua Green take issue with what they see to be a "false opposition between market and non-market culture" in that commercial media on YouTube has been a driving force in making videos appealing to mass audiences who then come to participate in creative acts through the venue (Burgess and Green 2009b: 76). In the West, labeling videos as amateur and professional have become confusing and, for many, irrelevant (Peters and Seier 2009: 193). Swedish professional YouTube personality PewDiePie nets several million US dollars annually. He frequents talk shows and is a household name among American youth. In China, some bloggers have become arguably as famous as stars represented by the movie and music industries. 


\section{YouTube's Carnival and other elements of play}

Academic discussions about YouTube frequently evince a certain mistrust. Alexandra Juhasz labels YouTube videos as banal (2009: 145), undemocratic (146), and possessing questionable ethics (145-146). In turn, scholarship on YouTube has also all but ignored the issue of humor. Indeed, when humor is mentioned, it more often than not takes the form of a condemnation of the videos' irreverence. This includes critiques of particular YouTube videos as cruel (Andén-Papadopoulos 2009: 22-23), insulting (Moor et al. 2010: 1538), racist (Andén-Papadopoulos 2009; Saul 2010: 471), unoriginal (Juhasz 2009: 147), violent (Andén-Papadopoulos 2009), and vulgar (Andén-Papadopoulos 2009: 23). Humor is also mentioned as instilling capitalist values in the guise of rebellion against the system (Juhasz 2009). Others warn of its insidious political effects in the context of corporate stealth campaigns disguised as fan creations that are in need of "inoculation" to protect the viewer (Lim and Ki 2007). In the handful of times that humor is mentioned without censure, it is often subsumed into a metanarrative concerning the ways that humor serves a higher power than itself, such as when it influences an electoral process. ${ }^{11}$

Scholarly reticence to approach YouTube humor as an aesthetic choice with its own cultural significance is somewhat surprising considering the veritable cornucopia of videos dedicated to making people laugh or, indeed, the centrality of humor in any culture. Arguably, scholars' mistrust of this antic frivolity comes from academia's inherited puritanical associations of the clergy with book learning. In part, avoiding the issue of humor is also simply linked to the cumbersome nature of unpacking what makes us laugh. For many, analyzing a joke has all the charm of dissecting a cat to prove one's love of animals. Yet to ignore this genre of visual creation is to miss a central component of the Internet, and perhaps the best of what this new media has to offer. As Dick Hebdige has pointed out, play, and popular culture more broadly, has a surprisingly sophisticated stance in that it "exploits its own contradictions instead of trying to resolve them" (Hebdige 1988: 140-141).

Online communities also demonstrate the vitality of Internet humor. Hacker culture is profoundly nuanced to a sense of playful defiance (Coleman 2013: 7; Coleman 2014; Danet 2005). One can even demonstrate a sense of wit and playfulness with computer code (Coleman 2013: 17, 93-94; Danet 2005: 234). Brenda Danet celebrates the profoundly playful nature of hacker code, stating, "Hackers cherish virtuoso play with symbols, words, typography, and spelling, often deliberately transgressing customary usage to challenge readability" (Danet 2005: 234). This demonstration of wit can put one at the top of a meritocratic hierarchy among hacker peers (Coleman 2013: 93-94).

Gabriella Coleman reminds us that this playful worldview has far-reaching implications for social solidarity when she posits "As this playful practice usually induces laughter - a state of bodily affect that enraptures an audiencehumor can potentially produce forms of collective awareness and shared sociality" (Coleman 2013: 103). She goes on to highlight the point that hacking as a 
group endeavor marks a tension between individuality (talent and humor) and ever-present sociality (Coleman 2013: 103).

Humor is a central way that people socialize while demonstrating individualistic intellectual prowess. Guobin Yang has noted, "Parody is as old as human civilization, but it has never enjoyed such a renaissance as in Chinese cyberspace today" (G. Yang 2009: 77). Yang further suggests, "Play has a spirit of irreverence. It always sits uncomfortably with power" (G. Yang 2009: 224). Indeed, the breadth of humorous expression on the Internet necessarily sets up political contention with the authorities, who have a far more limited set of responses ( $G$. Yang 2009: 78, 90).

According to Carl Jung, a trickster, like a poltergeist, is dreamlike and frightening in that his shape-changing has unpredictable and at times grotesque results (Jung 1972). The trickster's nightmarish potential is familiar to human needs and wants but he provides solace because we can say that we are not like him (Jung 1972: 144). Trickster Spirits, Court Jesters, stand-up comedians, and animated comedy such as South Park (1997) serve as ribald critics of society. Because of their particular place on the periphery of mainstream society, they are allowed to say things that no one else would dare.

The trickster spirit uses craftiness as a way of maximizing a structurally weak position including women maneuvering in patriarchal society (Landay 1998), and the slave in the antebellum South (Roberts 1989). Like the trickster spirit, YouTube humor displays a certain shape-shifting, irreverent, and often gleeful and unapologetic immaturity. It mocks historical figures and relives tragedies of a bygone age with a whimsical glint in its eye.

YouTube humor allows for the renegotiation of historical narratives. George Lipsitz reminds us of "the indispensable dialogue with the past that accompanies any present" (Lipsitz 1990: 81). For the YouTube videos that I examine here, the more obvious temporal, geographical, and cultural disjuncture immediately hits one's senses as Hitler rants about Bollywood films (Swiv2d 2009) or is informed that he has won the Nobel Peace Prize (hitlerrantsparodies 2009). Slamming history and the present moment together in this fashion is a profound revisualization of both historical events and the contemporary era.

In a similar fashion, these genres of YouTube videos provide laughter to ease the pains of the day. It may not always take place on an analytical level, but emotionally one immediately recognizes the important insights of these seemingly frivolous genres. This humor takes on very different meanings depending on one's knowledge of the historical context or the particular cultural milieu that they play with.

Benedict Anderson's examination of the birth of print media as unifying culture (2006) seems pertinent here. Print, he argued, was a unifying force that shaped people's ways of thought concerning religion and society and this played a very important role in the birth of nations. YouTube, and the Internet in general, demonstrate a similar unifying force, but on a global scale with near simultaneous transnational interactions that were unimaginable in the preInternet age. 
Rey Chow points out that Martin Heidegger and Walter Benjamin share a common view that aligns art with modernity as a profoundly disorienting event (R. Chow 1995: 5). Yet, at times, this is precisely the goal. Several scholars have drawn on Mikhail Bakhtin's theories of Carnival to explore the ways in which Internet humor in China allows for the suspension of everyday political oppression. ${ }^{12}$ Bakhtin's Carnival is blasphemous and irreverent; it is a celebration of life, with a thumb to the nose for those in power, that employs parody, laughter, and grotesque images to rebel against normal life (Herold 2011: 12).

Brazilian Carnival has been identified as a mischievous celebration of excess that simultaneously helps one to forget and to remember - a ritualized inversion that allows us to come to terms with the tragedies of everyday life (Goldstein 2003: 33; Scheper-Hughes 1992: 482). In her study of Brazilian shantytowns, Donna Goldstein states, "Unable to revolt, they use their laughter to oppose official Brazilian racial, class, and gender ideology. Laughter reveals the fault lines in social relations" (Goldstein 2003: 35). Irreverent humor about the most traumatic moments in our daily lives thereby becomes a form both of survival and resistance, in what Goldstein has called "laughter out of place" (Goldstein 2003). Humor can mark a coping mechanism for those surviving inhumane conditions, ranging from Jewish humor to that of people surrounded by lawless violence in shantytowns (Goldstein 2003).

We should not mistake this carnivalesque humor for a purely emancipatory act, however. Carnival shifts between being a conservative and a liberatory force, in that it is a sanctioned exception that arguably reinforces the boundaries of what is considered to be the norm (Goldstein 2003: 33; Scheper-Hughes 1992: 482). Irony and satire have also arguably always been part of establishing the social order (Bakhtin 1984). Perhaps, then, YouTube satire provides an outlet that gives the system a needed bit of flexibility, without which it would break. The Internet may be a carnivalesque sphere that fosters democratic impulses, while at the same moment adding to the resilience of an authoritarian State (Balla 2014: 227). Internet satire, and even outright condemnation of the powers that be, is thereby paradoxically both a subversion of the system and a way of helping to preserve it (Balla 2014: 227).

In truth, Bakhtin also allows for this "ambiguity" in the realm of folk humor. In Bakhtin's view, Carnival represents a "bare negation" of social values, whereas "folk humor denies, but it revives and renews at the same time" (Bakhtin 1984: 11-12). For my analysis here, the integrity of Carnival's position as a pure act of resistance is less important than Bakhtin's point about the "ambivalence" of folk culture (Bakhtin 1984: 12). In the YouTube videos under examination here, the salient issue is exactly this ambivalence. It is an act that simultaneously undermines and reifies normative beliefs, which both enforces order and paves the way to change the status quo.

As John Fiske has pointed out, Carnival is also profoundly concerned with bodies and an assumed lived materiality (Fiske 1989: 243). Online videos transcend this corporeal limitation, as well as time and space. We should also remember that many people we interact with in our offline lives are often no 


\section{Introduction}

more tactile than when online. We sit at a table and talk but do not touch-we experience each other through sight and sound in classrooms and meeting rooms, parks and office spaces.

One of the lines of inquiry that I will pursue in the following pages has to do with cultural proximity to the historical event being manipulated. Are Hitler videos more humorous to people in China and Taiwan because they are less threatening or does cultural proximity to videos such as these aid in viewers' appreciation? In what ways do musical appropriations translate more readily, and how can subtitles be used for subtler cultural appropriations? A central theme of this book is an examination of humor as a form of cultural critique that reinvents history and the contempory moment. This study also explores the manner in which English-language and Chinese-speaking digital cultures are in dialogue with each other, and the ways that we must rethink traditional paradigms about cultural understandings in the YouTube age.

\section{China at play}

Humor is one of the largest cultural gaps between China and the United States. Chinese humor frequently revolves around slapstick or puns that employ its many homonyms. This repertoire is expanded with Hitler rants and Cultural Revolution mash-ups drawing on contemporary American pop music, which are also uploaded onto Youku. The Chinese-language written commentary, which viewers post to the video sites on YouTube, shows a strong appreciation for this humor.

Part of the politically subversive nature of Internet play must be taken in the context of Chinese elites' long-standing mistrust of humor as undignified. Early Confucianism, for example, had a great disdain for publicly displayed humor, insisting that the proper gentleman should be reserved and somber at all times (Voci 2010: 123; W. Xu 2004). Viewed in conjunction with China's authoritarian style of rule, it is evident that political satire packs far more of an emotional punch than a similar spoof would have in the United States.

Christopher Rea states that historically in China, joviality could be deemed as nothing less than a medical malady, "Doctors of imperial China diagnosed excessively frequent or hearty laughter as being a symptom of mental illness, demon possession, food poisoning, poor circulation of the qi, or illness of the viscera. A common prescription: stop laughing" (Rea 2015: 7). Similarly, in the late Qing (1644-1912) and Republican (1912-1949) periods, writers continued to be mistrustful of the social and political effects of humor as distracting from the serious social matters of the day (Rea 2015: 13).

This was, of course, a contested domain. As Rea notes, there was a long history of humor in China that coexisted with this somber memorializing. This included street humor, jokes in periodicals, and books, among other venues. Importantly, Rea goes on to explore the range of writers who used this somber attitude as objects of satire. At the turn of the twentieth century, Western medicine and culture had influenced Chinese thought to the point that doctors began to advise laughing more for its health benefits (Rea 2015: 12). 
Youmo, a direct transliteration of "humor" in English, was introduced to Chinese in 1924 by social commentator Lin Yutang (Rea 2015: 38). Today, few Chinese speakers realize that youmo originated from English. This is primarily because they were raised with this term as part of their lexicon. It is also because youmo incorporates practices, attitudes, and cultural productions that existed long before the term. This included laughter, joking, play, and satire - all of which had a vibrant history in China.

Paul Pickowicz explored political humor in China that used leaders from the former Soviet Union, from Lenin to Gorbachev, as objects of derision as a safe topic for which the clear underlying criticism was really aimed at its own communist leaders (Pickowicz 2013: 60). These jokes, usually told over dinner or drinks, were particularly popular among well-educated urbanites, but in particular among party members who lived and breathed the contradictions of communist rhetoric as it met naked capitalist desire (Pickowicz 2013: 74). Not surprisingly, this form of humor also found its way to the Internet (Pickowicz 2013: 75).

As Guobin Yang points out, play on the Internet can have remarkably serious implications,

The most unorthodox, imaginative, and subversive ideas can be found in Chinese cyberspace. Authority of all kinds is subject to doubt and ridicule. Ordinary people engage in a broad range of political action and find a new sense of self, community, and empowerment.

(G. Yang 2009: 2)

For the great many who cannot afford to travel internationally, or even within their own country, Internet venues such as YouTube represent a profound introduction to the outside world. Digital culture helps to reinvision the past, present, and future, with an almost tactile expression of play. Seemingly frivolous videos posted to YouTube, Tudou, and Youku are opening pathways to new aesthetics and sensibilities of what is considered to be funny. These videos serve as a funhouse mirror - an intentional mimetic distortion with a wink toward the playfulness of that very endeavor. Perhaps more subtly, they are also transforming people's understanding of self and other, history and the contemporary moment.

\section{Notes}

1 See Bell 1991; Cody 2009, 2011; Hull 2012; Jaffe 2009a, 2009b; Silverstein 2006.

2 See Baron et al. 2005; Gershon 2012; Schieffelin et al. 2011; Squires 2004, 2010, 2012.

3 See Berkowitz 2005; Bird 2005; Coman 2005; Coman and Rothenbuhler 2005; Danet 2005; Liebes and Blondheim 2005.

4 At the time the video was created Next Animation Studio was called NEXT Media.

5 For more on this, see H. Li 2011: 79-80; Shirk 2011: 14.

6 For more on train crash scandals, see Link and Qiang 2013: 85-86.

7 For more on speaking in code, see Link and Qiang 2013. 


\section{Introduction}

8 For more on this, see Clark 2012; Link and Qiang 2013; B. Meng 2011.

9 Interview. July 2, 2014.

10 Interview. July 2, 2014.

11 See, for example, Hediger 2009; Powell 2010.

12 For examples of this, see Herold 2011: 12, 2012; H. Li 2011: 72; B. Meng 2011: 46; G. Yang 2009: 77, 89-90.

\section{References}

Abu-Lughod, Lila. 2002. "Egyptian Melodrama-Technology of the Modern Subject?" In Media Worlds: Anthropology on a New Terrain, eds. Faye D. Ginsburg, Lila AbuLughod, and Brian Larkin, 115-133. Berkeley, CA: University of California Press.

Adorno, Theodor W. 2000 [1941]. "On Popular Music." In On Record: Rock, Pop, and the Written Word, eds. Simon Frith and Andrew Goodwin, 301-314. New York: Routledge.

Alemán, Stephanie W. 2012. “Technology, Representation, and the 'E-thropologist': The Shape-Shifting Field among Native Amazonians.” In Human No More: Digital Subjectivities, Unhuman Subjects, and the End of Anthropology, eds. Neil L. Whitehead and Michael Wesch, 147-156. Boulder, CO: University Press of Colorado.

Allen, Robert C. 1983. "On Reading Soaps: A Semiotic Primer.” In Regarding Television: Critical Approaches-An Anthology, ed. E. Ann Kaplan, 97-108. Frederick, MD: The American Film Institute.

Allison, Anne. 2012. "Afterword." In Human No More: Digital Subjectivities, Unhuman Subjects, and the End of Anthropology, eds. Neil L. Whitehead and Michael Wesch, 231-234. Boulder, CO: University Press of Colorado.

Althuser, Louis. 2014 [1970]. On the Reproduction of Capitalism: Ideology and Ideological State Apparatuses, G.M. Goshgarian (trans.). New York: Verso.

Andén-Papadopoulos, Kari. 2009. "US Soldiers Imaging the Iraq War on YouTube." Popular Communication: International Journal of Media and Culture 7(1): 17-27.

Anderson, Benedict. 2006 [1983]. Imagined Communities: Reflections on the Origin and Spread of Nationalism. New York: Verso Press.

Appadurai, Arjun. 1996. Modernity at Large: Cultural Dimensions of Globalization. Minneapolis, MN: University of Minnesota Press.

Audin, Judith. 2016. "An Interactionist Perspective on Irony in the Street-Level Bureaucracies of Beijing." In Irony, Cynicism and the Chinese State, eds. Hans Steinmüller and Susanne Brandstädter, 101-121. New York: Routledge.

Bakhtin, Mikhail. 1984 [1965]. Rabelais and His World. Helene Iswolsky (trans.). Bloomington, IN: Indiana University Press.

Balla, Steven J. 2014. "Health System Reform and Political Participation on the Chinese Internet." China Information 28(2): 214-236.

Baron, Naomi, Lauren Squires, Sara Tench, and Marshal Thompson. 2005. "Tethered or Mobile? Use of Away Messages in Instant Messaging by American College Students." In Mobile Communications: Re-Negotiation of the Social Sphere, eds. Rich Ling and Per Pederson, 293-312. London: Springer.

Barthes, Roland. 1972 [1957]. Mythologies. New York: Hill and Wang.

$B B C$ News. 2016a. "China's 'flooding' social media with fake posts.” May 20, www.bbc. com/news/technology-36340514. Accessed June 1, 2016.

BBC News. 2016b. "China's 'Great Firewall' blocks its creator.” April 5. www.bbc.com/ news/blogs-news-from-elsewhere-35968855. Accessed June 1, 2016. 
Bell, Allan. 1991. The Language of News Media. Oxford: Basil Blackwell.

Benjamin, Walter. 1969 [1936]. "The Work of Art in the Age of Mechanical Reproduction." In Illuminations, ed. Hannah Arendt, 217-251. New York: Schocken Books.

Berkowitz, Dan. 2005. "Telling What-A-Story News Through Myth and Ritual: The Middle East as Wild West." In Media Anthropology, eds. Eric W. Rothenbuhler and Mihai Coman, 210-219. Thousand Oaks, CA: Sage Publications.

Bird, S. Elizabeth. 2005. "CJ's Revenge: A Case Study of News as Cultural Narrative." In Media Anthropology, eds. Eric W. Rothenbuhler and Mihai Coman, 220-228. Thousand Oaks, CA: Sage Publications.

Boellstorff, Tom. 2008. Coming of Age in Second Life: An Anthropologist Explores the Virtually Human. Princeton, NJ: Princeton University Press.

Boellstorff, Tom. 2016. "For Whom the Ontology Turns: Theorizing the Digital Real." Current Anthropology 57(4): 387-407.

Boellstorff, Tom, Bonnie Nardi, Celia Pearce, and T.L. Taylor. 2012. Ethnography and Virtual Worlds: A Handbook of Method. Princeton, NJ: Princeton University Press.

Brandstädter, Susanne. 2016. "The Rebel as Trickster and the Ironies of Resisting in Contemporary China." In Irony, Cynicism and the Chinese State, eds. Hans Steinmüller and Susanne Brandstädter, 122-137. New York: Routledge.

Burgess, Jean and Joshua Green. 2009a. YouTube: Online Video and Participatory Culture. Malden, MA: Polity Press.

Burgess, Jean and Joshua Green. 2009b. "The Entrepreneurial Vlogger: Participatory Culture Beyond the Professional-Amateur Divide." In The YouTube Reader, eds. Pelle Snickars and Patrick Vonderau, 89-107. Stockholm: National Library of Sweden.

Chow, Rey. 1995. Primitive Passions: Visuality, Sexuality, Ethnography, and Contemporary Chinese Cinema. New York: Columbia University Press.

Clark, Paul. 2012. Youth Culture in China: From Red Guards to Netizens. Cambridge: Cambridge University Press.

Cody, Francis. 2009. "Daily Wires and Daily Blossoms: Cultivating Regimes of Circulation in Tamil India's Newspaper Revolution," Journal of Linguistic Anthropology 19(2): 286-309.

Coleman, Gabriella. 2013. Coding Freedom: The Ethics and Aesthetics of Hacking. Princeton, NJ: Princeton University Press.

Coleman, Gabriella. 2014. Hacker, Hoaxer, Whistleblower, Spy: The Many Faces of Anonymous. New York: Verso.

Coman, Mihai. 2005. "Cultural Anthropology and Mass Media: A Processual Approach." In Media Anthropology, eds. Eric W. Rothenbuhler and Mihai Coman, 46-55. Thousand Oaks, CA: Sage Publications.

Coman, Mihai and Eric W. Rothenbuhler. 2005. "The Promise of Media Anthropology." In Media Anthropology, eds. Eric W. Rothenbuhler and Mihai Coman, 1-12. Thousand Oaks, CA: Sage Publications.

Cool, Jennifer. 2012. "The Mutual Co-Construction of Online and Onground in Cyberorganic: Making an Ethnography of Networked Social Media Speak to Challenges of the Posthuman." In Human No More: Digital Subjectivities, Unhuman Subjects, and the End of Anthropology, eds. Neil L. Whitehead and Michael Wesch, 11-32. Boulder, CO: University Press of Colorado.

Danet, Brenda. 2005. "Ritualized Play, Art, and Communication on Internet Relay Chat." In Media Anthropology, eds. Eric W. Rothenbuhler and Mihai Coman, 229-246. Thousand Oaks, CA: Sage Publications.

de Certeau, Michel. 1984. The Practice of Everyday Life. Berkeley, CA: UC Press. 


\section{Introduction}

Dyer, Richard. 2000 [1979]. "In Defense of Disco." In On Record: Rock, Pop, and the Written Word, eds. Simon Frith and Andrew Goodwin, 410-418. Routledge: New York.

Fernback, Jan. 1997. "The Individual within the Collective: Virtual Ideology and the Realization of Collective Principles." In Virtual Culture: Identity and Communication in Cybersociety, ed. Steven Jones, 36-54. Thousand Oaks, CA: Sage Publications.

Fiske, John. 1989 [1987]. Television Culture. London: Methuen.

Gershon, Ilana. 2012. The Breakup 2.0: Disconnecting over New Media. Ithaca, NY: Cornell University Press.

Ginsburg, Faye. 2005. "Media Anthropology: An Introduction.” In Media Anthropology, eds. Eric W. Rothenbuhler and Mihai Coman, 17-25. Thousand Oaks, CA: Sage Publications.

Goldstein, Donna M. 2003. Laughter Out of Place: Race, Class, Violence, and Sexuality in a Rio Shantytown. Berkeley, CA: University of California Press.

Gong, Haomin and Xin Yang. 2010. "Digitized Parody: The Politics of Egao in Contemporary China." China Information 24(1): 3-26.

Graffam, Gray. 2012. "Avatar: A Posthuman Perspective on Virtual Words." In Human No More: Digital Subjectivities, Unhuman Subjects, and the End of Anthropology, eds. Neil L. Whitehead and Michael Wesch, 131-146. Boulder, CO: University Press of Colorado.

Habermas, Jürgen. 1991 [1962]. The Structural Transformation of the Public Sphere: An Inquiry into a Category of Bourgeois Society. Boston, MA: MIT Press.

Hamilton, Annette. 2002. "The National Picture: Thai Media and Cultural Identity." In Media Worlds: Anthropology on a New Terrain, eds. Faye D. Ginsburg, Lila AbuLughod, and Brian Larkin, 152-170. Berkeley, CA: University of California Press.

Haraway, Donna. 1991 [1985]. "A Cyborg Manifesto: Science, Technology, and Socialist-Feminism in the Late Twentieth Century." In Simians, Cyborgs and Women: The Reinvention of Nature, ed. Donna Haraway, 149-181. New York: Routledge.

Hebdige, Dick. 1988. Hiding in the Light: On Images and Things. New York: A Comedia Book.

Hediger, Vinzenz. 2009. "YouTube and the Aesthetics of Political Accountability." In The YouTube Reader, eds. Pelle Snickars and Patrick Vonderau, 252-265. Stockholm: National Library of Sweden.

Herold, David Kurt. 2011. "Introduction: Noise, Spectacle, Politics: Carnival in Chinese Cyberspace." In Online Society in China: Creating, Celebrating, and Instrumentalising the Online Carnival, eds. David Kurt Herold and Peter Marolt, 1-19. New York: Routledge.

Herold, David Kurt. 2012. "Escaping the World: A Chinese Perspective on Virtual Worlds." Journal of Virtual Worlds Research 5(2): 1-16.

hitlerrantsparodies. 2009. "Hitler is informed he has won the Nobel Peace Prize." Uploaded November 16, 2009. www.youtube.com/watch?v=MZy_5Dd7SQU\&feature $=$ related. Accessed December 5, 2010.

Hull, Matthew S. 2012. Government of Paper: The Materiality of Bureaucracy in Urban Pakistan. Oakland, CA: University of California Press.

Internet World Stats. n.d. Internet World Stats-China. www.internetworldstats.com/asia/ cn.htm. Accessed January 13, 2005.

Jacobs, Andrew. 2014. "It's Another Perfect Day in Tibet!" New York Times, July 21. http://mobile.nytimes.com/2014/07/22/world/asia/trending-attractive-people-sharingupbeat-news-about-tibet-.html partner $=r s s \& e m c=r s s \& s m i d=$ tw-nytimesworld \& $\mathrm{r}=2 \&$ referrer. Accessed July 22, 2014. 
Jaffe, Alexandra. 2009a. "Introduction: The Sociolinguistics of Stance." In Stance: Sociolinguistic Perspectives, ed. Alexandra Jaffe, 3-28. Oxford: Oxford University Press.

Jaffe, Alexandra. 2009b. "Stance in a Corsican School: Institutional and Ideological Orders." In Stance: Sociolinguistic Perspectives, ed. Alexandra Jaffe, 119-145. Oxford: Oxford University Press.

Jenkins, Henry. 2008. Convergence Culture: Where Old and New Media Collide. New York: New York University Press.

Jenkins, Henry. 2009. "What Happened Before YouTube." In YouTube: Online Video and Participatory Culture, eds. Jean Burgess and Joshua Green, 109-125. Malden, MA: Polity Press.

Jones, Steven G. ed. 1998. Cybersociety 2.0: Revisiting Computer-Mediated Communication and Community. London: New Media Cultures.

Juhasz, Alexandra. 2009. "Learning the Five Lessons of YouTube: After Trying to Teach There, I Don't Believe the Hype.” Cinema Journal 48(2): 145-150.

Jung, Carl G. (R.F.C. Hull translator). 1972 [1902]. Four Archetypes: Mother Rebirth Spirit Trickster. London: Routledge \& Kegan Paul.

Landay, Lori. 1998. Madcaps, Screwballs, and Con Women: The Female Trickster in American Culture. Philadelphia, PA: University of Pennsylvania Press.

Lange, Patricia. 2008. "(Mis)Conceptions about YouTube." In Video Vortex Reader: Responses to YouTube, eds. Geert Lovink and Sabine Niederer, 87-100. Amsterdam: Institute of Network Cultures.

Larkin, Brian. 2002. "The Materiality of Cinema Theaters in Northern Nigeria." In Media Worlds: Anthropology on a New Terrain, eds. Faye D. Ginsburg, Lila Abu-Lughod, and Brian Larkin, 319-336. Berkeley, CA: University of California Press.

Latham, Kevin. 2016. "Differentiating Cynicisms: Irony, Cynicism and the New Media in Contemporary China." In Irony, Cynicism and the Chinese State, eds. Hans Steinmüller and Susanne Brandstädter, 155-173. New York: Routledge.

Li, Hongmei. 2011. "Parody and Resistance on the Chinese Internet." In Online Society in China: Creating, Celebrating, and Instrumentalising the Online Carnival, eds. David Kurt Herold and Peter Marolt, 71-88. New York: Routledge.

Liebes, Tamar, and Menahem Blondheim. 2005. "Myths to the Rescue: How Live Television Intervenes in History." In Media Anthropology, eds. Eric W. Rothenbuhler and Mihai Coman, 188-198. Thousand Oaks, CA: Sage Publications.

Lim, Joon Soo and Eyun-Jung Ki. 2007. "Resistance to Ethically Suspicious Parody Video on YouTube: A Test of Inoculation Theory." J\&MC Quarterly 84(4): 713-728.

Link, Perry and Xiao Qiang. 2013. "From Grass-Mud Equestrians to Rights-Conscious Citizens: Language and Thought on the Chinese Internet." Restless China, eds. Perry Link, Richard P. Madsen, and Paul G. Pickowicz, 83-107. New York: Rowman and Littlefield.

Lipsitz, George. 1990. Time Passages: Collective Memory and American Popular Culture. Minneapolis, MN: University of Minnesota Press.

Lule, Jack. 2005. "News as Myth: Daily News and Eternal Stories." In Media Anthropology, eds. Eric W. Rothenbuhler and Mihai Coman, 101-110. Thousand Oaks, CA: Sage Publications.

Mandel, Ruth. 2002. "A Marshall Plan of the Mind: The Political Economy of a Kazakh Soap Opera." In Media Worlds: Anthropology on a New Terrain, eds. Faye D. Ginsburg, Lila Abu-Lughod, and Brian Larkin, 211-228. Berkeley, CA: University of California Press. 


\section{Introduction}

Mankekar, Purnima. 2002. "Epic Contests: Television and Religious Identity in India." In Media Worlds: Anthropology on a New Terrain, eds. Faye D. Ginsburg, Lila AbuLughod, and Brian Larkin, 134-151. Berkeley, CA: University of California Press.

Marcus, George. 2012. "Forward." In Ethnography and Virtual Worlds: A Handbook of Method, eds. Tom Boellstorff, Bonnie Nardi, Celia Pearce, and T.L. Taylor, xiii-xvii. Princeton, NJ: Princeton University Press.

McLuhan, Marshal. 1973 [1964]. Understanding Media: The Extensions of Man. New York: McGraw Hill.

McTiernan, John Campbell Jr., dir. 1988. Die Hard. Los Angeles, CA: 20th Century Fox.

Meng, Bingchun. 2011. "From Steamed Bun to Grass Mud Horse: E Gao as Alternative Political Discourse on the Internet." Global Media and Communication 7(1): 33-51.

Miller, Daniel and Don Slater. 2000. The Internet: An Ethnographic Approach. New York: Berg Press.

Moor, Peter J. Ard Heuvelman, and Ria Verleur. 2010. Flaming on YouTube. Computers in Human Behavior (26): 1536-1546.

Moskowitz, Marc L. 2010. Cries of Joy, Songs of Sorrow: Chinese Pop Music and its Cultural Connotations. Honolulu: University of Hawai'i Press.

Moskowitz, Marc L. 2011. "The Power of the Popular." In Popular Culture in Taiwan: Charismatic Modernity, ed. Marc L. Moskowitz, 1-22. New York: Routledge Press.

Nardi, Bonnie A. 2010. My Life as a Night Elf Priest: An Anthropological Account of World of Warcraft. Ann Arbor, MI: The University of Michigan Press.

Nolan, Christopher, dir. 2000. Memento. Los Angeles, CA: Summit Entertainment.

Ong, Aihwa. 1999. Flexible Citizenship: The Cultural Logics of Transnationality. Durham, NC: Duke University Press.

Osburg, John. 2016. "Morality and Cynicism in a 'Grey' World." In Irony, Cynicism and the Chinese State, eds. Hans Steinmüller and Susanne Brandstädter, 47-62. New York: Routledge.

Parker, Trey and Matt Stone. 1997. South Park. Los Angeles, CA: Comedy Central.

Peters, Kathrin and Andrea Seier. 2009. "Home Dance: Mediacy and Aesthetics of the Self on YouTube." In The YouTube Reader, eds. Pelle Snickars and Patrick Vonderau, 187-203. Stockholm: National Library of Sweden.

Peterson, Mark A. 2005. "Performing Media: Toward an Ethnography of Intertextuality." In Media Anthropology, eds. Eric W. Rothenbuhler and Mihai Coman, 129-138. Thousand Oaks, CA: Sage Publications.

Pickowicz, Paul G. 2013. "Political Humor in Postsocialist China: Transnational and Still Funny. Restless China, eds. Perry Link, Richard P. Madsen, and Paul G. Pickowicz, 59-80. New York: Rowman and Littlefield.

Powell, Larry. 2010. "Obama and the Obama Girl: YouTube, Viral Videos, and the 2008 Presidential Campaign." In Communicator-in-Chief: How Barack Obama Used New Media Technology to Win the White House, eds. John Allen Hendricks, and Robert E. Denton Jr., 83-104. Lanham, MD: Lexington Books.

Rea, Christopher. 2015. The Age of Irreverence: A New History of Laughter in China. Berkeley, CA: University of California Press.

Roberts, Hal. 2011. "Local Control: About 95\% of Chinese Web Traffic is Local." Watching Technology: The Berkman Center for Internet \& Society. Posted August 15, 2011. http://blogs.law.harvard.edu/hroberts/2011/08/15/local-control-about-95-of-chineseweb-traffic-is-local/. Accessed July 24, 2014.

Roberts, John Willie. 1989. From Trickster to Badman: The Black Folk Hero in Slavery and Freedom. Philadelphia, PA: University of Pennsylvania Press. 
Saul, Roger. 2010. "KevJumba and the Adolescence of YouTube." Educational Studies 46: 457-477.

Schein, Louisa. 2002. "Mapping Hmong Media in Diasporic Space." In Media Worlds: Anthropology on a New Terrain, eds. Faye D. Ginsburg, Lila Abu-Lughod, and Brian Larkin, 229-244. Berkeley, CA: University of California Press.

Scheper-Hughes, Nancy. 1992. Death without Weeping: The Violence of Everyday Life in Northeast Brazil. Berkeley, CA: University of California Press.

Schieffelin, Bambi B., G. Gones, and R. Smith. 2011. "When Friends who Talk Together Stalk Together." In The Handbook of Language Socialization, eds. A. Duranti, E. Ochs, and B.B. Schieffelin. Malden, MA: Wiley-Blackwell.

Shirk, Susan L. 2011. "Changing Media, Changing China." In Changing Media, Changing China, ed. Susan L. Shirk, 1-37. Oxford: Oxford University Press.

Silverstein, Michael 2006. "How Knowledge Begets Communication Begets Knowledge: Textuality and Contextuality in Knowing and Learning." Intercultural Communication Review (Tokyo) 5: 31-60.

Snickars, Pelle and Patrick Vonderau, eds. 2009. The YouTube Reader. Stockholm: National Library of Sweden.

Squires, Lauren. 2004. "College Students in Multimedia Relationships: Choosing, Using, and Fusing Communication Technologies." American University TESOL Working Papers 2. www.american.edu/cas/tesol/pdf/upload/WP-2004-Squires-Students-in-Multi media.pdf

Squires, Lauren. 2010. “Enregistering Internet Language.” Language and Society 39(4): 457-492.

Squires, Lauren. 2012. "Whos Punctuating What? Sociolinguistic Variation in Instant Messaging." In Orthography as Social Action: Scripts, Spelling, Identity and Power, eds. Alexandra Jaffe, Jannis Androutsopoulos, Mark Sebba, and Sally Johnson, 289-324. Berlin, Germany: Mouton de Gruyter (Language and Social Processes).

Steinmüller, Hans. 2016. "Introduction." In Irony, Cynicism and the Chinese State, eds. Hans Steinmüller and Susanne Brandstädter, 1-13. New York: Routledge.

Strangelove, Michael. 2010. Watching YouTube: Extraordinary Videos by Ordinary People. Toronto: University of Toronto Press.

swiv2d. 2009. "Hitler doesn't understand Bollywood films." Uploaded December 11, 2009. www.youtube.com/watch? $v=$ O0M2u_rs61o\&feature=related. Accessed December 23, 2010.

Szablewicz, Marcella. 2014. "The 'Losers' of China's Internet: Memes as 'Structures of Feeling' for Disillusioned Young Netizens." China Information 28(2): 259-275.

Taylor, T.L. 2006. Play Between Worlds: Exploring Online Game Culture. Cambridge, MA: The MIT Press.

Tufekci, Zeynep. 2012. "We Were Always Human.” In Human No More: Digital Subjectivities, Unhuman Subjects, and the End of Anthropology, eds. Neil L. Whitehead and Michael Wesch, 33-47. Boulder, CO: University Press of Colorado.

Voci, Paola. 2010. China on Video: Smaller Screen Realities. New York: Routledge.

Wesch, Michael. 2007. "Web 2.0...The Machine is using us." Uploaded January 31, 2007. www.youtube.com/watch?v=6gmP4nk0EOE. Accessed December 2, 2012.

Wesch, Michael. 2008. "An Anthropological Introduction to YouTube. Presented at the Library of Congress. June 23, 2008." Uploaded January 31, 2008. www.youtube.com/ watch?v=TPAO-1Z4_hU. Accessed February 15, 2012.

Whitehead, Neil L. and Michael Wesch. 2012. "Introduction: Human No More.” In Human No More: Digital Subjectivities, Unhuman Subjects, and the End of Anthropology, 


\section{Introduction}

eds. Neil L. Whitehead and Michael Wesch, 1-10. Boulder, CO: University Press of Colorado.

Wilk, Richard R. 2002. "Television, Time, and the National Imaginary in Belize." In Media Worlds: Anthropology on a New Terrain, eds. Faye D. Ginsburg, Lila AbuLughod, and Brian Larkin, 171-186. Berkeley, CA: University of California Press.

Wu, Xu. 2007. Chinese Cyber Nationalism: Evolution, Characteristics, and Implications. New York: Lexington Books.

$\mathrm{Xu}$, Weihe. 2004. "The Confucian Politics of Appearance-and Its Impact on Chinese Humor." Philosophy East and West 54(4): 514-532.

Yan, Sophia. 2015. "Beijing uses banned social media to promote Xi's U.S. Visit." CNN Money, September 27. http://money.cnn.com/2015/09/27/technology/china-facebookxi-jinping-ban/

Yang, Guobin. 2009. The Power of the Internet in China. New York: Columbia University Press.

Yang, Guobin. 2012. "A Chinese Internet? History, Practice, and Globalization.” Chinese Journal of Communication 5(1): 49-54.

Yang, Mayfair Mei-hui. 2002. "Mass Media and Transnational Subjectivity in Shanghai: Notes on (Re)Cosmopolitanism in a Chinese Metropolis." In Media Worlds: Anthropology on a New Terrain, eds. Faye D. Ginsburg, Lila Abu-Lughod, and Brian Larkin, 189-210. Berkeley, CA: University of California Press.

YouTube statistics. n.d. www.youtube.com/yt/press/statistics.html. Accessed June 24, 2013. Zhang, Ning. 2014. "Web-based Backpacking Communities and Online Activism in China: Movement Without Marching." China Information 28(2): 276-296. 
In turn, this is often in dialogue with popular culture from South Korea and the United States. The periphery also becomes a slippery conceptual tool when one broadens the discussion from transnational East Asian dialogues to globalized spaces of discourse. For the videos I have presented here, as well as other Chinese-oriented content, the sites for these YouTube videos cannot be seen as a Western space as much as a transnational or border-crossing domain among Chinese-language speakers. It is a free zone to share, to interact, to accuse, to berate, and to laugh (either at each other or with each other). It is a space to reify sociopolitical differences or to transcend them-and, at times, to paradoxically do both in the same moment.

\section{Notes}

1 To view this performance with its original sound, see Kwwkwwkww 2007.

2 See Hi 2007.

3 For a more detailed analysis of this issue in relation to Mandopop, see Moskowitz 2009, 2010.

4 Cawelti 2001: 205.

5 Goodwin 2000: 260.

6 Judging from his use of complex characters, and the content of several other videos that he posted on his YouTube page, I am guessing that Orangebigbig is a male from Hong Kong.

7 These statements were all taken from the Tudou site: huaxiazi487 2010.

8 For more on this, see Moskowitz 2010.

9 See, for example, the comments posted to madeinmother 2010.

10 For more on this, see Moskowitz 2010, 2011.

\section{References}

Baudrillard, Jean. 1981. For a Critique of the Political Economy of the Sign. New York: Telos Press Publishing.

Benjamin, Walter. 1969 [1936]. "The Work of Art in the Age of Mechanical Reproduction." In Illuminations, ed. Hannah Arendt, 217-251. New York: Schocken Books.

Bolter, Jay and Richard Grusin. 2000 [1999]. Remediation: Understanding New Media. Cambridge, MA: The MIT Press.

Cawelti, John G. 2001. "The Concept of Formula in the Study of Popular Culture." In Popular Culture: Production and Consumption, eds. C. Lee Harrington and Denise D. Bielby, 203-209. Oxford: Blackwell Publishers.

Chou, Jay (Zhou Jielun). 2001. “Ninja,” (renzhi 忍者). In the album, Fantasy (fantexi 范特西). Taipei: Alpha Music, International.

Couldry, Nick and Anna McCarthy. 2004. "Orientations: Mapping MediaSpace." In MediaSpace: Place, Scale and Culture in a Media Age, eds. Nick Couldry and Anna McCarthy, 1-18. New York: Routledge.

Darley, Andrew. 2000. Visual Digital Culture: Surface Play and Spectacle in New Media Genres. New York: Routledge.

Dikötter, Frank. 2010. Mao's Great Famine: The History of China's Most Devastating Catastrophe, 1958-1962. New York: Bloomsbury Publishing.

Frith, Simon. 1996. Performing Rites: On the Value of Popular Music. Cambridge, MA: Harvard University Press. 
Gong, Haomin and Xin Yang. 2010. "Digitized Parody: The Politics of Egao in Contemporary China." China Information 24(1): 3-26.

Goodwin, Andrew. 2000 [1988]. "Sample and Hold: Pop Music in the Digital Age of Reproduction." In On Record: Rock, Pop, and the Written Word, eds. Simon Frith and Andrew Goodwin, 258-273. New York: Routledge.

HDCYT. 2007. "Charlie bit my finger-again!” Uploaded May 22, 2007. www.youtube. com/watch?v=_OBlgSz8sSM. Accessed January 5, 2015.

Hi. 2007. “Chou, Jay (Zhou Jielun)—Ninja,” (Zhou Jielun-renzhi 周杰伦-忍者). Uploaded August 11, 2007. www.youtube.com/watch?v=n9JCtaPgAtg. Accessed July 15, 2014.

huaxiazi 487 (话匣子 487). 2010. “Jay Chou Ninja Red Army version,” (Zhou Jielun renzhi hongjun ban 周杰伦 忍者红军版). Uploaded August 9, 2010. www.tudou.com/ programs/view/PKoOZK0GsvA/?spm=a2h0k.8191414.0.0. Accessed August 24, 2014.

Jenkins, Henry. 2009. "What Happened Before YouTube." In YouTube: Online Video and Participatory Culture, eds. Jean Burgess and Joshua Green, 109-125. Malden, MA: Polity Press.

JiBaSiZe-XL. 2010. “Communists ft. Lady Gaga.” Uploaded August 16, 2010. www. youtube.com/watch?v=cKO51FYW15U. Accessed July 15, 2014.

Kwwkwwkww. 2007. “Cross Chishui 4 times with ingenious military move,"四渡赤水 出奇兵 Extracted from the Long March Song Cycle 长征组歌 (1976). Uploaded September 14, 2007. www.youtube.com/watch?v=Rh63s2jyRXU. Accessed July 31, 2014.

madeinmother. 2010. “Cultural Revolution Jay Chou,”红军版周杰伦 忍者. Uploaded July 9, 2010. www.youtube.com/watch? $=$ =xP9kfVfRcE\&feature $=$ related. Accessed November 6, 2010.

McLuhan, Marshal. 1973 [1964]. Understanding Media: The Extensions of Man. New York: McGraw Hill.

Meng, Bingchun. 2011. "From Steamed Bun to Grass Mud Horse: E Gao as Alternative Political Discourse on the Internet." Global Media and Communication 7(1): 33-51.

Mittler, Barbara. 2012. A Continuous Revolution: Making Sense of Cultural Revolution Culture. Cambridge, MA: Harvard University Press.

Moores, Shaun. 2004. "The Doubling of Place: Electronic Media, Time-Space Arrangements and Social Relationships." In MediaSpace: Place, Scale and Culture in a Media Age, eds. Nick Couldry and Anna McCarthy, 21-36. New York: Routledge.

Moskowitz, Marc L. 2009. "Mandopop Under Siege: Culturally Bound Criticisms of Taiwan's Pop Music." Popular Music 28(1): 69-83.

Moskowitz, Marc L. 2010. Cries of Joy, Songs of Sorrow: Chinese Pop Music and its Cultural Connotations. Honolulu: University of Hawai'i Press.

Moskowitz, Marc L. 2011. "The Power of the Popular." In Popular Culture in Taiwan: Charismatic Modernity, ed. Marc L. Moskowitz, 1-22. New York: Routledge Press.

orangebigbig. 2010. “(Cultural Revolution Korean) 紅軍 want nobody but 毛主席.” Uploaded August 14, 2010. www.youtube.com/watch?v=QvHIlQBk_jQ\&feature= related. Accessed November 6, 2010.

Park, Jin-young. 1998. "Honey." In the album, Even After 10 Years. Seoul, South Korea: JYP Entertainment.

Voci, Paola. 2010. China on Video: Smaller Screen Realities. New York: Routledge.

Wesch, Michael. 2008. "An Anthropological Introduction to YouTube. Presented at the Library of Congress. June 23, 2008.” Uploaded January 31, 2008. www.youtube.com/ watch?v=TPAO-1Z4_hU. Accessed February 15, 2012. 
Wonder Girls. 2008. "Nobody.” In the album, The Wonder Years: Trilogy. Seoul, South Korea: JYP Entertainment.

Wondergirls. 2008. "Wonder Girls (원더걸스)—NOBODY (Kor. Ver)." Uploaded December 14, 2008. www.youtube.com/watch?v=QZBn1e9pr2Q. Accessed December 25, 2016.

Xloserkidx. 2006. "Numa Numa." Uploaded February 7, 2006. www.youtube.com/ watch?v=60og9gwKh1o. Accessed January 5, 2015.

yehzhaofeng. 2010. "Chinese Red Army-We Will Rock You." Uploaded August 13, 2010. www.youtube.com/watch?v=XGJiiOLekxY. Accessed June 22, 2013. 
The humor in all of these examples is one of connecting disjointed realities - a re-examination of an often-painful past subjected to playful torture through the interjection of contemporary commercialism, sexuality, and selfserving individualism. In appropriating these historical narratives in this way, one disarms them. The more wary might warn that this has the potential to trivialize, and thereby erase, the past. George Lipsitz draws on Nobel prize laureate Czelaw Milosz in suggesting that events such as the Holocaust were so horrific that many find it easier to just forget rather than "take on the burdens and responsibilities of remembering" (Lipsitz 1990: 22). Yet the humor of these videos is based on remembering the events, for if it was not Hitler ranting about iPad or Tiger Woods the videos would not be funny. YouTube provides video makers with a playing ground to reinvent history and rethink the contemporary moment. In doing so they create a space for viewers to re-envision the world that they live in. They allow us to re-examine this horrific past with a humorous vision that reappropriates through a conscious mimetic excess. In reshaping historical narratives in this fashion we do not forget. Rather, we internalize forces of evil and absorb their power in a repetitive and visually ritualized cannibalistic rite.

\section{Notes}

1 For more on this, see Dikötter 1995; Farrer 2002: 32; Morris 2004; Moskowitz 2008.

2 For more on this, see Moskowitz 2008.

3 For more on this issue, see Hartig 2013.

4 For more on the oddly fond racial profiling of Jews in China, see Sebag-Montefiore 2012.

5 For more on the ways that Chinese people looked to Nazi Germany as a model for the paths that China might take in creating a national identity, see Jones 2001: 50.

6 For more on Google's acquisition of YouTube, see Burgess and Green 2009: 1.

7 For more on this, see Burgess and Green 2009: 32-35; McDonald 2009: 387.

8 The YouTube video was removed but an online report (ETtoday n.d.) outlines her sermon using several lengthy direct quotes.

9 See, for example, Rapturous Floating Cloud for You 2011; Tragedy No. 1. 2010.

\section{References}

101-words-press. 2011. "Chinese Toilet Paper, Hitler and 30 Mins.” http://101press.wordpress.com/2011/08/12/chinese-toilet-paper-hitler-and-30-mins/. Accessed July 19, 2013.

Allen, Robert C. 1983. “On Reading Soaps: A Semiotic Primer.” In Regarding Television: Critical Approaches-An Anthology, ed. E. Ann Kaplan, 97-108. Frederick, MD: The American Film Institute.

andyroweiii. 2010.“Hitler finds out Lady Gaga's screening his calls.” Uploaded April 27, 2010. www.youtube.com/watch?v=YJDAtb2B5EM. Accessed December 23, 2016.

Apple, Wendy, dir. 2004. The Cutting Edge: The Magic of Movie Editing. Los Angeles, CA: ACE.

Barthes, Roland. 1972 [1957]. Mythologies. New York: Hill and Wang.

BouncingMemory. 2016. "Hitler reacts to watching 'Re: Zero-Starting Life in Another World,'” (Xitele dui Re: cong ling kaishi deyi shijie shenghuode fanyin 希特勒對 
Re: 從零開始的異世界生活的反應). Uploaded August 4, 2016. www.youtube.com/ watch? $\mathrm{v}=\mathrm{H} 3 \mathrm{Oa} 6 \mathrm{cEH} 3 \mathrm{JU}$. Accessed December 20, 2016.

Burgess, Jean and Joshua Green. 2009. "The Entrepreneurial Vlogger: Participatory Culture Beyond the Professional-Amateur Divide." In The YouTube Reader, eds. Pelle Snickars and Patrick Vonderau, 89-107. Stockholm: National Library of Sweden.

Cameron, James, dir. 2009. Avatar. Los Angeles, CA: 20th Century Fox.

Derrida, Jacques. 1973. Speech and Phenomena. Evanston, IL: Northwestern University Press.

Dikötter, Frank. 1995. Sex, Culture, and Modernity in China: Medical Science and the Construction of Sexual Identities in the Early Republican Period. Hawai'i: University of Hawai'i Press.

Eber, Irene. 2005. "Overland and By Sea: Eight Centuries of the Jewish Presence in China." Chinese Journal of International Law 4(1): 235-256.

ETtoday. n.d. "Believers in Jesus get Diamonds? Female Pastor Guo Meijiang: Already picked up more than 50 (Xin Jesu zhuanshi? Nü mushi Guo Meijiang: yijian 50 ji ke 信耶穌得鑚石? 女牧師郭美江：已撿50幾顆.” www.ettoday.net/news/20131217/30 7462.htm. Accessed December 18, 2016.

Farrer, James. 2002. Opening Up: Youth Sex Culture and Market Reform in Shanghai. Chicago, IL: University of Chicago Press.

Fein, Bernard. 1965 [1965-1971]. Hogan's Heroes. Los Angeles, CA: The CBS Network.

Fish, Isaac. 2011. "Great Dictator: In China, Hitler is a Subject of Endless Fascination and Represents Many Meanings, Not All of Them Bad." Tablet Journal. www.tablet mag.com/jewish-arts-and-culture/theater-and-dance/75920/great-dictator. Accessed July $19,2013$.

French, Howard W. 2006. "China Hails a Good Nazi and Makes Japan Take Notice." New York Times International, March 15. www.nytimes.com/2006/03/15/international/ asia/15letter.html?_r=0. Accessed January 12, 2015.

Gallenberger, Florian, dir. 2009. City of War: The Story of John Rabe. Berlin: H\&V Entertainment.

Gao, Bei. 2011. "The Chinese Nationalist Government's Policy toward European Jewish Refugees during World War II." Modern China 37(2): 202-237.

Gao Bei. 2013. Shanghai Sanctuary: Chinese and Japanese Policy toward European Jewish Refugees during World War II. New York: Oxford University Press.

gto180202. 2013. "Hitler shouts about national highway shark vs. a duck car-blocking incident," (Xitele ganjiao guodao yingpisha xiaoya - dangche shijian 希特勒幹噍國道 硬皮渻VS小鴨 擋車事件). Uploaded February 23, 2013. www.youtube.com/watch?v $=4011 \mathrm{dFGOe1E}$. Accessed December 25, 2016.

Hartig, Falk. 2013. "What China Loves about Germany: Soccer, Cars and Hitler." The CPD Blog. http://uscpublicdiplomacy.org/index.php/newswire/cpdblog_detail/what_ china_loves_about_germany_soccer_cars_and_hitler/. Accessed July 19, 2013.

Hirschbiegel, Oliver, dir. 2004. Downfall (der untergang). Berlin: Constantin Film.

hitlerrantsparodies. 2009a. "Hitler's glued to his chair." Uploaded November 30, 2009. www.youtube.com/watch?v=L9LO4EUJ0ZI\&NR=1. Accessed December 16, 2010.

hitlerrantsparodies. 2009b. "Hitler is informed he has won the Nobel Peace Prize." Uploaded November 16, 2009. www.youtube.com/watch?v=MZy_5Dd7SQU\&feature $=$ related. Accessed December 5, 2010.

hitlerrantsparodies. 2009c. "Hitler is informed that Tiger Woods might have had an affair with Hitler's wife." Uploaded August 11, 2009. www.youtube.com/watch?v= K5xWBowWIQ8. Accessed December 15, 2010. 
hitlerrantsparodies. 2010a. "Hitler is informed about the Apple iPad." Uploaded January 27, 2010. www.youtube.com/watch? $\mathrm{v}=$ fuA_OUL9 $\log \&$ feature=related. Accessed December 15, 2010.

hitlerrantsparodies. 2010b. "Hitler reviews: Avatar." Uploaded January 4, 2010. www. youtube.com/watch?v=FNyVxx1JaYk. Accessed December 23, 2010.

holysword12. 2008. "Hitler loves his waffles." Uploaded April 27 2008. www.youtube. com/watch? $\mathrm{v}=\mathrm{nF} 4 \mathrm{nhhL}$ WW90\&feature=related. Accessed December 23, 2010.

Hsu, Jenny. 2014. "Taiwan restaurant apologizes for pasta dish called 'Long Live the Nazis." The Wall Street Journal —China, August 19. http://blogs.wsj.com/chinarealtime/2014/08/19/taiwan-restaurant-apologizes-for-pasta-dish-called-long-live-thenazis/. Accessed January 12, 2014.

Huangchinkai. 2016. "Zhou Ziyu shivers when being forced to apologize, Hitler is angry," (Zhou Ziyu fadou bei qiangpo daoqian, Xitele shengqi le. 周子瑜發抖被強迫 念道歉信, 希特勒生氣了). Uploaded January 15, 2016. www.youtube.com/watch? v= C6okmfgvKa4. Accessed December 20, 2016.

Jenkins, Henry. 2009. "What Happened Before YouTube.” In YouTube: Online Video and Participatory Culture, eds. Jean Burgess and Joshua Green, 109-125. Malden, MA: Polity Press.

Jones, Andrew F. 2001. Yellow Music: Media Culture and Colonial Modernity in The Chinese Jazz Age. Durham, NC: Duke University Press.

KakashiBallZ. 2010a. "Hitler and Fegelein ENTER THE MATRIX." Uploaded July 28, 2010. www.youtube.com/watch?v=akABoyJfJTg. Accessed December 17, 2010.

KakashiBallZ. 2010b. "Hitler loves Cheetos!" Uploaded September 2, 2010. www. youtube.com/watch?v=7oPYRdb2QvU\&feature=related. Accessed December 15, 2010.

Kirby, William C. 1984. Germany and Republican China. Stanford, CA: Stanford University Press.

Knight Rider KR (Pili Youxia KR 霹雾游侠KR). n.d. "Funny: Hitler is very unhappy with the iPad (Chinese Subtitles)," ([Gaoxiao] Xitele dui iPad hen bu shuang (Zhongwen zimu) [搞笑] 希特勒對iPad很不爽 (中文字幕). No upload date. http://v.youku.com/v show/id_XMTQ5ODQzMTE2.html? from=s1.8-1-1.2\&spm=a2h0k.8191407.0.0. Accessed December 29, 2016.

Kubrick, Stanley, dir. 1964. Dr. Strangelove or: How I Learned to Stop Worrying and Love the Bomb. Los Angeles, CA: Columbia Pictures.

Liner, Hao. 2013. “"Meijiang' five diamonds makes Hitler angry," ("Meijiang” wuke zhuanshi rang Xitele fanu [美江]五顆鑚石讓希特勒發怒). Uploaded December 24, 2013. www.youtube.com/watch?v=gcxRAGLdvTk. Accessed October 7, 2017.

Lipsitz, George. 1990. Time Passages: Collective Memory and American Popular Culture. Minneapolis, MN: The University of Minnesota Press.

Little DouDou Who Loves Korean Fashion (Ai hanliu de xiaodoudou 爱韩流的小豆豆). 2012. "Amazing remix! Hitler version of Uncle Bird PSY's amazing song 'Gangnam Style' Gangnam style HITLER remix!!” (Shenhunyin! Xitele ban PSY niaoshu shenqu “jiangnan style” Gangnam Style HITLER Remix!! 神混音! 希特勒版PSY鸟叔神曲 “江南style” Gangnam Style HITLER Remix!! Uploaded September 29, 2012. www. tudou.com/programs/view/QrT6EZ74xJI/?spm=a2h0k.8191414.0.0. Accessed December $25,2016$.

Liu, Fu (劉芙). 2014. “Hitler-Taizhong's Bus Rapid Transit System episode," (XiteleTaizhong de BRT ban 希特勒一台中的BRT版). Uploaded July 20, 2014. www. youtube.com/watch?v=iBTCum7cw34. Accessed December 22, 2016. 
Lundemo, Trond. 2009. "In the Kingdom of Shadows: Cinematic Movement and Its Digital Ghost." In The YouTube Reader, eds. Pelle Snickars and Patrick Vonderau, 314-329. Stockholm: National Library of Sweden.

McDonald, Paul. 2009. "Digital Discords in the Online Media Economy: Advertising versus Content versus Copyright." In The YouTube Reader, eds. Pelle Snickars and Patrick Vonderau, 387-405. Stockholm: National Library of Sweden.

Morris, Andrew D. 2004. "Baseball, History, the Local and the Global in Taiwan." In The Minor Arts of Daily Life: Popular Culture in Taiwan, eds. Andrew D. Morris David K. Jordan, and Marc L. Moskowitz, 176-203. Honolulu: University of Hawai'i Press.

Moskowitz, Marc L. 2008. "Multiple Virginity, Barbarian Prince Charmings, and Other Contested Realities in Taipei's Foreign Club Culture.” Sexualities 11(3): 327-335.

plankhead. 2010. "Hitler reacts to the Hitler parodies being removed from YouTube." Uploaded April 20, 2010. www.youtube.com/watch? $\mathrm{v}=\mathrm{kBO} 5 \mathrm{dh} 9 \mathrm{qrIQ} \&$ feature $=$ relate d. Accessed December 15, 2010.

Rapturous Floating Cloud for You. (Wei ni xiaohun de fuyun 为你销魂的浮云). 2011. “Top Secret: The woman who made Hitler unleash World War 2," (Juemi: Yi ge rang Xitele fadong erzhan de nüren 绝密: 一个让希特勒发动二战的女人). Uploaded September 25, 2011. www.tudou.com/programs/view/0RE8SyUosKY/?spm=a2h0k.81 91414.0.0. Accessed December 23, 2016.

Ridley, Charles, dir. 1941. American Germany Calling or The Panzer Ballet.

Riefenstahl, Leni, dir. 1934. Triumph of the Will. Berlin: Universum Film AG.

Roth, Philip. 1969. Portnoy's Complaint. New York: Random House.

Ryderyoshi737. 2012. "Chen Pingwei, a motorcycle repair shop's boss and Head of State Hitler face off," (Jiche xing laoban Chen Pingwei he yuanshou Xitele de hu qiang 機車 行老闆陳平偉和元首希特勒的互唅). Uploaded July 29, 2012. www.youtube.com/ watch?v=1uulYphlExM. Accessed December 22, 2016.

Sebag-Montefiore, Clarissa. 2012. "Oh, to be Jewish in China." New York Times, October 2. http://latitude.blogs.nytimes.com/2012/10/02/oh-to-be-jewish-in-china/?_php=true\& _type $=$ blogs\&_r=0. Accessed October 16, 2014.

Shen, Qinna. 2011. "Revisiting the Wound of a Nation: The 'Good Nazi' John Rabe and the Nanking Massacre." Seminar 47(5): 661-680.

Sherr, Ian. 2014. "Player Tally for 'League of Legends' Surges." Wall Street Journal, January 27. http://blogs.wsj.com/digits/2014/01/27/player-tally-for-league-of-legendssurges/. Accessed December 15, 2016.

Shore, David. 2004-today. House. Los Angeles, CA: Fox.

Sontag, Susan. 1977. On Photography. New York: Farrar, Straus and Giroux.

swiv2d. 2009a. "Hitler doesn't understand Bollywood films." Uploaded December 11, 2009. www.youtube.com/watch?v=O0M2u_rs61o\&feature=related. Accessed December 23, 2010.

swiv2d. 2009b. "Hitler hates Canada." October 26, 2010. www.youtube.com/watch? $\mathrm{v}=1 \mathrm{NUhOuNwFzA \& NR=1.} \mathrm{Accessed} \mathrm{December} \mathrm{25,} 2016$.

Tarantino, Quentin, dir. 2009. Inglorious Basterds. New York: The Weinstein Company and Universal Pictures.

TheZ1621209. 2010. “An Episode of Downfall: Hitler orders McDonald's delivery," (Huimei diguo zhi Xitele jiao Maidanglao waisong 毀滅帝國之希特勒叫麥當勞外送). Uploaded October 29, 2010. www.youtube.com/watch?v=4ru7AtrRTUw. Accessed December 20, 2016.

Tragedy No. 1. (Beiju No. 1. 悲剧 No. 1.) 2010. “Hitler hilarious Dungeon Fighter video," (Xitele gaoxiao ban DNF shipin 希特勒搞笑版DNF视频). Uploaded May 16, 2010. 
www.tudou.com/programs/view/2fMWgquTKbw/?spm=a2h0k.8191414.0.0. Accessed December 23, 2016.

Wachowski, Wachowski and, dir. 1999. The Matrix. Warner Brothers.

Winn, Patrick. 2011. "Chinese Lovebirds in Nazi Garb." Global Post, September 4. www. globalpost.com/dispatches/globalpost-blogs/the-rice-bowl/chinese-lovebirds-nazi-garb. Accessed January 12, 2015.

Xu Jianhong (許劍虹). 2016. “Taiwan high-school students hold Nazi flag while participating in school's anniversary event," (Taiwan gaozhongsheng gaoju nacui qi cianjia xiaoqing 台灣高中生高舉納粹旗參加校慶). China Times. (Posted on December 23). Accessed December 25, 2016. www.chinatimes.com/realtimenews/20161223005881260408

xwmr146. 2010. “Egao Hitler One Piece version,” (Egao Xitele OP ban 恶搞希特勒 OP版). Uploaded July 11, 2010. www.tudou.com/programs/view/1Q415i-YzVE/?spm= a2h0k.8191414.0.0. Accessed December 23, 2016.

You, Dali (游大星). 2013. “You Dali's Post: Hitler's ire about League of Legends," (You Dali: Xitele dui LOL de fennu【游大星】希特勒對LOL的憤怒). Uploaded December 17, 2013. www.youtube.com/watch?v=rJqCYmVt-wo. Accessed December 23, 2016. 
science fiction, combined with their unusual English skills and elite education, meant that they were also far more articulate and thoughtful about the materials we discussed than most people I had showed the videos to in either the US or Taiwan. As such, they were in many ways the perfect people to interview but, for that very reason, they were somewhat atypical. Whether we should think of them as an anomaly that is not reflective of the whole, or as an exceptionally expressive voice of their generation, I will leave to the reader. Regardless, these interviews are a reminder that "youth culture" cannot be envisioned as one homogeneous group, even within one nation. Their comments also served as an important reminder that cultural proximity does not inevitably lead to greater affinity, as is often claimed.

For the club members, as well the creators and fans of humorous videos revolving around the Star Trek universe, these visual creations are an emblem of a more hopeful future. They offer a dreamscape that provides a respite from our daily travails and the more dystopian reality that accosts us daily in the news. Star Trek's characters also provide us with the tools to explore alternative versions of society, and ourselves; of who we are and who we want to be. That these fan-created videos appropriate these creative building blocks in such a playful and joyous nature may be dismissed as frivolous or shallow by some. But they are also a reminder of the best of what humanity has to offer - of our creativity, our playfulness, and our willingness to laugh at ourselves and with each other. And, in the true Star Trek ethos, they do so with love and hope, rather than with derision.

\section{Notes}

1 For more on this, see Geraghty 2006.

2 Daniel Bernardi presents Star Trek fans' discussion about whether or not Ferengi are meant to signify Jewishness (1998: 171-175). A casual search on the Internet will bring up a number of other discussions ranging from overtly denying the connection, to self-professed neo-Nazis who assert that the Ferengi are certainly Jewish, warning against the show because of its Jewish cast members.

3 Women's fiction revolving around Star Trek is primarily a female response to a massmediated framework that, more often than not, caters to male audiences (Bacon-Smith 1991: 240-241). For an exploration of the psychological dynamic of women who write erotic fantasy that is centered around Spock and Kirk, see Bacon-Smith 1991: 247-250. For another example of sado-masochistic scenes, see alexanderabd 2006.

4 See alexanderabd 2006; bionic1013 2009; ImaginarySanity 2009; JohnnyDeppHouse4us 2010; talitha78onLJ 2009; and there are many more.

5 For more on this, see Consalvo 2004; Dove-Viebahn 2007.

6 C. Liu 2016. See also, J. Xia 2016.

7 For more on this, see Moskowitz 2004; Moskowitz 2010.

\section{References}

Abrams, J.J., dir. 2009. Star Trek. Los Angeles, CA: Paramount Pictures.

Abrams, J.J., dir. 2013. Star Trek Into Darkness. Los Angeles, CA: Paramount Pictures. 
alexanderabd. 2006. "Star Trek + Nine Inch Nails = Closer." Uploaded September 8, 2006. www.youtube.com/watch? $v=3 u x T p y C d r i Y \&$ feature=related. Accessed December 15, 2010.

Atlanta23410. 2009. "Star Trek meets Mean Girls." Uploaded December 14, 2009. www. youtube.com/watch?v=5ipGo4rCklk. Accessed December 15, 2016.

Atlanta23410. 2010. “Kirk/Spock-'MONSTER' Lady Gaga.” Uploaded January 29, 2010. www.youtube.com/watch?v=yIQno79JSTk\&NR=1. Accessed December 15, 2016.

Bacon-Smith, Camille. 1991. Enterprising Women: Television Fandom and the Creation of Popular Myth. Philadelphia, PA: University of Pennsylvania Press.

Berman, Rick and Michael Piller. 1993. Star Trek: Deep Space 9. Los Angeles, CA: Paramount Domestic.

Bernardi, Daniel L. 1998. Star Trek and History: Race-ing Toward a White Future. New Brunswick, NJ: Rutgers University Press.

bionic1013. 2009. “Radar-Star Trek XI (2009), Kirk/Spock.” Uploaded July 7, 2009. www.youtube.com/watch? $\mathrm{v}=\mathrm{dQQ} 6 \mathrm{BsNLH9E} \&$ feature=related. Accessed December 18, 2016.

Bordo, Susan. 1993. "Reading the Male Body." Michigan Quarterly Review 32(4): 696-737.

Bradley, Dan, dir. 2012. Red Dawn. Los Angeles, CA: Contrafilm.

Bus-Online Official Video (Bashi zaixian guanfangpin 巴士在线官方视). 2016. “Lost in the Stars-Star Trek 3: Star Trek Beyond," (Lost in the Stars-xingji mihang 3 chaoyue xingcheng 《Lost in the Stars》—《星际迷航3: 超越星辰》). Uploaded August 24, 2016. www.tudou.com/programs/view/zO49R3anEpE/?spm=a2h0k.81914 14.zO49R3anEpE.A.usVfdp. Accessed February 18, 2017.

Consalvo, Mia. 2004. "Borg Babes, Drones, and the Collective: Reading Gender and the Body in Star Trek." Women's Studies in Communication 27(2): 177-203.

Dove-Viebahn, Aviva. 2007. "Embodying Hybridity, (En)gendering Community: Captain Janeway and the Enactment of a Feminist Heterotopia on Star Trek: Voyager." Women's Studies: An Inter-Disciplinary Journal 36(8): 597-618.

Gaga, Lady. 2009. "Monster." In the album, The Fame Monster. Los Angeles, CA: Interscope.

Geraghty, Lincoln. 2006. "A Network of Support: Coping with Trauma Through Star Trek Fan Letters." The Journal of Popular Culture 39(6): 1002-1024.

greatertalent. 2006. "Leonard Nimoy: The origin of Spock's greeting." Uploaded October 26, 2006. www.youtube.com/watch? $\mathrm{v}=\mathrm{G} 1 \mathrm{~d} 83$ XOORP0. Accessed December 18, 2016.

$\mathrm{Gu}, \mathrm{Amo}$ (谷阿莫). 2016. “\#349 [Gu Amo] 6 minutes to watch [the Film] 'I Want to be Captain' 'Star Trek' 1 \& 2." (\#349 [Gu Amo] 6 fen zhong kan wan wo yao dang jiangzhang de dianying 'Xingjizhengba Star Trek' 1+2. \#349【谷阿莫】6分鐘看完 我要當艦長的電影《星際爭霸戰 Star Trek》1+2集). Uploaded August 31, 2016. www.youtube.com/watch?v=V_GUgJyjrX8. Accessed February 4, 2017.

Houson Old Monkey Babysitter (Houson houmu 猴姆). n.d. "Hilarious: old monkey babysitter exclusive: Star Trek into Darkness explosive laughter," (Gao Xiao: Houmu dujia: “Xingji mihang: anheiwujie” baoxiao [搞笑]【猴姆独家】《星际迷航：暗黑无界》). (570,290 views). No upload date. http://v.youku.com/v_show/id_XNzczMDU1NTc2. html?from=s1.8-1-1.2\&spm=a2h0k.8191407.0.0. Accessed February 18, 2017.

ImaginarySanity. 2009. "You Spin Me Round 2009 (Kirk/Spock)." Uploaded on May 21, 2009. www.youtube.com/watch? $=$ WT-OV7wfe38\&feature=related. Accessed December $18,2010$.

Jenkins, Henry. 2006. Fans, Bloggers, and Gamers: Exploring Participatory Culture. New York: NYU Press. 
JohnnyDeppHouse4us. 2010. "Kirk/Spock-Mind in the gutter//Slash//." Uploaded

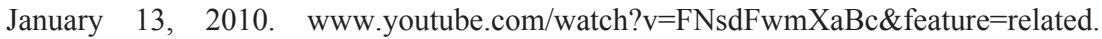
Accessed December 18, 2010.

Karl's Basket of Laughs. (Kale de huanxiao luokuang 卡勒的歡笑籮筐). 2013. “Honest trailers-honest trailers 'Star Trek into Darkness: Star Trek,", (Dianying laoshi shuo. Honest Trailers—“anheiwujie: xingjizhanba”. Zhongwenzimu. chengshi yugao “電影老 實說 Honest Trailers-《闇黑無界: 星際爭霸戰》(中文字幕) (另譯: 誠實預告). Uploaded September 5, 2013. www.youtube.com/watch?v=qA5x5F1qQDc. Accessed February 19, 2017.

Kring, Tim, creator. 2006. Heroes. NBC.

Lin, Justin, dir. 2016. Star Trek Beyond. Los Angeles, CA: Paramount Pictures.

Liu, Cixin (trans. Ken Liu). 2014 [2006]. The Three-Body Problem (Remembrance of Earth's Past). New York: Tor Books.

Liu, Cixin (trans. Ken Liu). 2016. "The Worst of All Possible Universes and the Best of All Possible Earths: Three-Body and Chinese Science Fiction." In Invisible Planets: Contemporary Chinese Science Fiction in Translation, ed. Ken Liu (trans.). New York: Tor Books.

McNary, Dave. 2016. “'Star Trek Beyond' earns \$31.3 million in China Debut.” Variety. Posted September 4, 2016. http://variety.com/2016/film/news/box-office-star-trekbeyond-china-1201852068/. Accessed January 7, 2017.

Meyers, Jessica. 2016. “'Star Trek Beyond' dominates Box Office in China.” Los Angeles Times. Posted September 13, 2016. www.latimes.com/entertainment/envelope/cotown/ la-et-ct-china-box-office-20160913-snap-story.html. Accessed March 7, 2017.

Misra, Ria. 2015. "This is what it's like to write science fiction novels in China," Io9. Uploaded January 14, 2015. http://io9.gizmodo.com/this-is-what-its-like-to-writescience-fiction-novels-i-1679541435. Accessed January 8, 2017.

Moskowitz, Marc L. 2004. "Yang-Sucking She-Demons: Penetration, Fear of Castration, and other Freudian Angst in Modern Chinese Cinema." In The Minor Arts of Daily Life: Popular Culture in Modern Taiwan, eds. Andrew D. Morris David K. Jordan, and Marc L. Moskowitz, 204-217. Honolulu: University of Hawai'i Press.

Moskowitz, Marc L. 2010. Cries of Joy, Songs of Sorrow: Chinese Pop Music and its Cultural Connotations. Honolulu: University of Hawai'i Press.

Ong, Aihwa. 1999. Flexible Citizenship: The Cultural Logics of Transnationality. Durham, NC: Duke University Press.

Rooney, Ben. 2015. "'Star Trek' fan builds company headquarters in shape of USS Enterprise.” CNN Money. Posted May 26, 2015. http://money.cnn.com/2015/05/26/ news/star-trek-enterprise-headquarters/index.html. Accessed January 7, 2017.

Scott, Ridley. 1982. Blade Runner. Los Angeles, CA: The Ladd Company.

talitha78onLJ. 2009. "Poker Face, Star Trek XI (Spock/Kirk)." Uploaded September 21, 2009. www.youtube.com/watch? $v=$ AEghawKig_0\&feature $=$ fvw. Accessed December $18,2010$.

Tartaglione, Nancy. 2016. “ 'Star Trek Beyond' gets more Chinese investment with Huahua Media now aboard." Deadline Hollywood. Posted June 22, 2016. http://deadline. com/2016/06/huahua-media-star-trek-beyond-investment-china-paramount-1201777164/. Accessed January 7, 2017.

Verhoeven, Paul, dir. 1997. Starship Troopers. Los Angeles, CA: TriStar Pictures.

Waters, Mark, dir. 2004. Mean Girls. Los Angeles, CA: Paramount Pictures.

Wise, Robert, dir. 1979. Star Trek: The Motion Picture. Los Angeles, CA: Paramount Pictures. 
Woledge, Elizabeth. 2005. "From Slash to the Mainstream: Female Writers and Gender Bending Men." Extrapolation 46(1): 50-56.

Xia, Jia. 2016. "What Makes Chinese Science Fiction Chinese?" In Invisible Planets: Contemporary Chinese Science Fiction in Translation, ed. Ken Liu (trans.). New York: Tor Books.

Zemeckis, Robert. 1985. Back to the Future. Los Angeles, CA. Universal Pictures.

Zemeckis, Robert, dir. 2004. The Polar Express. Los Angeles, CA: Castle Rock Entertainment. 
influence throughout East Asia and beyond, is a perfect exploratory point to examine the ways in which transnational production becomes part of a dialogue with the audience, one that engages with musical and visual images of the past and present, here and there.

Similarly, Perhaps Love forcefully demonstrates the importance of shared understandings, such as the ways that it draws on common understandings of religious frameworks which provide important tools for understanding the motivations of characters who are trapped in forces beyond their control - in their past lives, their present incarnations, and the next. This shared cultural understanding is necessary to be an informed viewer, both in better comprehending the characters themselves, as well as the ways in which a character's behavior draws on particular cultural understandings of regional differences concerning gender and politics. Seeing Hong Kong productions is thereby both a form of knowing and creative appropriation - for the moviemakers, for the audience, and for fans who create their own narratives with the new tools that are available to them.

\section{Notes}

1 Because I am specifically looking at the Mandopop industry here I have chosen to use pinyin for Mandarin, rather than a romanization of Cantonese pronunciations.

2 The 2006 Hong Kong Film Awards were: Best Actress, Best Art Direction, Best Cinematography, Best Costume and Makeup Design, Best Original Film Score, Best Original Film Song. It was nominated for Best Director, Best Film Editing, Best Screenplay, and Best Sound Design. The 2006 Golden Horse Awards were: Best Actress, Best Cinematography, Best Director, Best Original Film Song. The nominations were: Best Action Choreography, Best Art Direction, Best Film Editing, Best Makeup and Costume Design, Best Original Film Score, Best Sound Effects, and Best Visual Effects.

3 As late as 1977, 70 percent of Hong Kong's radio broadcasts were Western music (Chen and Chen 1997: 5).

4 P. Fu 2003: 60. For more on this, see H. Ceng 1997: 79, 84; Chen and Chen 1997: 3-4.

5 For more on this, see Chen and Chen 1997: 3-4.

6 In the 1960s, Hong Kong also benefited from Filipino musicians living in Hong Kong (J. Wong 1997: 106).

7 For more on this, see J. Wong 1997: 98.

8 For more on this, see H. Ceng 2000: 192; M. Zhang 1997; Y. Zhu 2000: 25. Part of this was because in 1972 copyright legislation was enacted which attracted a good deal of new talent (J. Wong 1997: 107). It was really only in the mid-1970s, as Hong Kong's economy was booming and there was a new consumer market, that Cantopop began to compete with the Mandopop market in Hong Kong (J. Lee 1992: 132).

9 In 1982 a Japanese textbook which whitewashed Japan's role in China created another wave of songs focusing on Chinese identity, expressed through songs like "I am Chinese" (Wo shi Zhongguoren) or Hong Kong Singer Zhang Mingmin's "My Chinese Heart (Wo de Zhongguo Xin) which were broadcasted repeatedly at the same time that Sino-British negotiations were underway on Hong Kong's repatriation (F. Feng 1982; M. Zhang 1982; for more on this, see Gold 1993: 922; W. Ho 2000: 344; Y. Zhu 2000: 255). Similarly, if self-censorship was the rule of thumb in Hong Kong's music industry, the Tiananmen massacre made Hong Kong pop more political 
than it had ever been (W. Ho 2000: 345; K. Liew 2003: 224). Cantopop and Mandopop songs were used to rally Hong Kong protests against the Tiananmen massacre in Beijing (Erni 1998: 61). Though this faded within a couple of years, it highlights the political framing of a seemingly apolitical musical genre.

10 For more on the relationship between Chinese movie industries and pop music see Chen and Chen 1997: 4; W. Jian and Z. Guo 2004; W. Tsai 2002: 6-7.

11 For more on this, see Chen and Chen 1997: 5.

12 For more on this, see Chen and Chen 1997: 5.

13 For more on this, see H. Ceng 1998: 189-190.

14 For more on this, see J. Zheng et al. 2004: 56.

15 For more on this, see K. Liew 2003: 225.

16 For more on this in relation to the Singaporean market, see K. Liew 2003: 227.

17 For more on this film, see Moskowitz 2004.

18 To be more precise, there are two occasions that Zhou Xun's character sings outside of the musical. One instance is in a flashback when she is performing at a cabaret set ten years earlier. The other is when she is peddling a pedicab. Both occasions are portrayed as just a normal person singing with no embellishment, however.

19 For more on depictions of north as masculine and south as feminine, see Baranovitch 2003: 20-22, 130-131; de Kloet 2005a: 230-233; 2005b: 611; 2005c: 322-323; Farrer 2002; H. Huang 2003: 186, 195; Jones 1994: 159; Moskowitz 2010.

20 Women zhijian de juli xiangcha buguo haoli.

21 For more on gender stereotypes in Shanghai, see Farrer 2002.

22 J. Ji and J. Cheung 2005.

23 J. Cheung 2005c.

24 A second set of transitional themes occurs with buses. A third set of liminal imagery is water and ice.

25 Fangshou ba. Rang wo chenwei ni de huiyi. Sun Na.

26 J. Cheung 2005a.

27 J. Cheung $2005 \mathrm{c}$.

28 For both videos, I use the date of uploading to YouTube. The production dates may have been earlier if the videos were pulled and re-uploaded.

29 The fact that East Asian audiences are aware that Takeshi Kaneshiro's father is Japanese, adds to the transnational feel of the film. Takeshi Kaneshiro's presence is also iconic of Taiwan's much-lauded cultural difference from China because of its fiftyyear history as Japan's colony.

30 For more on this, see Moskowitz 2010.

31 See Adorno 2000; Benjamin 1969.

\section{References}

Adorno, Theodor W. 2000 [1941]. "On Popular Music.” In On Record: Rock, Pop, and the Written Word, eds. Simon Frith and Andrew Goodwin, 301-314. New York: Routledge.

Allen, Robert C. 1983. “On Reading Soaps: A Semiotic Primer.” In Regarding Television: Critical Approaches-An Anthology, ed. E. Ann Kaplan, 97-108. Frederick, MD: The American Film Institute.

Baranovitch, Nimrod. 2003. China's New Voices: Popular Music, Ethnicity, Gender, and Politics, 1978-1997. Berkeley, CA: University of California Press.

Benjamin, Walter. 1969 [1936]. "The Work of Art in the Age of Mechanical Reproduction.” In Illuminations, ed. Hannah Arendt, 217-251. New York: Schocken Books.

Ceng, Huizhao (曾慧佳). 1997. Social Changes Reflected on the Verses of Popular Music in Taiwan 1945-1995 (You liuxing yinyue de geci yanbian lai kan Taiwan de shehui 
bianqian 由流行音樂的歌詞演變萊看台灣的社會變遷). Taipei: Wunan Library Publication House.

Ceng, Huizhao. 2000 [1998] Looking at Taiwan's Society through Taiwan's Pop Songs (Cong liuxing gechu kan Taiwan shehui). Taipei: Guiguan Books (Guiguan tushu).

Chan, Peter, dir. 2005. Perhaps Love (Ruguo ai 如果爱). Hong Kong: Applause Pictures.

Chen Jialing (陳嘉玲) and Chen Qianjun (陳倩君). 1997. “Introduction: Culture is Nothing More than Common Affairs,” (Xulun: Wenhua buguo pinchang shi 緒論 : 文化 不過平常事). In The Practice of Affect: Studies in Hong Kong Popular Song Lyrics (Qingan de shijian: Xianggang liuxing ge yanjiu 情感的實踐: 香港流行歌詞研究), ed. Stephen C.K. Chan (Chen Qingqiao 陳清僑), 1-23. Hong Kong: Oxford University Press.

Cheng, Xiaodong (程小東), dir. 1987. A Chinese Ghost Story (Qian nü youhun 倩女幽 魂). Hong Kong: Golden Princess Production Company, Ltd.

Cheung, Jacky (Zhang Xueyou 張學友). 2005a. “Men are Born to be Jealous," (Nanren ben gai duji 男人本該妒忌). In the album, Perhaps Love: The Movie Soundtrack (Ruguo ai: dianying yuansheng dadie 如果愛 電影原聲大碟). Taipei: EMI.

Cheung, Jacky (Zhang Xueyou 張學友). 2005b. “Perhaps Love," (Ruguo Ai 如果愛). In the album, Perhaps Love: The Movie Soundtrack (Ruguo ai: dianying yuansheng dadie 如果愛電影原聲大碟). Taipei: EMI.

Cheung, Jacky (Zhang Xueyou 張學友). 2005c. “You Do Love Me," (Ni shi ai wo de 妳 是愛我的). In the album, Perhaps Love: The Movie Soundtrack (Ruguo ai: dianying yuansheng dadie 如果愛電影原聲大碟). Taipei: EMI.

Chun, Allen. 1996. "Fuck Chineseness: On the Ambiguities of Ethnicity as Culture as Identity." Boundary 2 23(2): 111-138.

de Kloet, Jeroen. 2005a. "Authenticating Geographies and Temporalities: Representations of Chinese Rock in China." Visual Anthropology 18: 229-255.

de Kloet, Jeroen. 2005b. "Popular Music and Youth in Urban China-The Dakou Generation." The China Quarterly 183: 609-626.

de Kloet, Jeroen. 2005c. "Sonic Sturdiness: The Globalization of 'Chinese' Rock and Pop." Critical Studies in Media Communication 22(4): 321-338.

Dyer, Richard. 2000 [1979]. "In Defense of Disco." In On Record: Rock, Pop, and the Written Word, eds. Simon Frith and Andrew Goodwin, 410-418. Routledge: New York.

Erica_101289. 2008. “Perhaps Love 如果.愛 (你是爱我的 You Do Love Me).” Uploaded October 24, 2008. www.youtube.com/watch? $\mathrm{v}=$ HAshYNsgRsY\&feature=related. Accessed December 10, 2010.

Erni, John Nguyet. 1988. "Like a Culture-Notes on Pop Music and Popular Sensibility in Decolonized Hong Kong." Hong Kong Cultural Studies Bulletin 8(9): 55-63.

Farrer, James. 2002. Opening Up: Youth Sex Culture and Market Reform in Shanghai. Chicago, IL: University of Chicago Press.

Feng, Feifei (鳳飛飛). 1982. “I am Chinese,” (Wo shi Zhongguoren 我是中國人). In the album, I am Chinese (Wo shi Zhongguoren 我是中國人). Taipei: Gelin Record Company.

Fu, Poshek. 2003. Between Shanghai and Hong Kong: The Politics of Chinese Cinemas. Stanford, CA: Stanford University Press.

Gaiman, Neil. 2006 [2005]. Anansi Boys. New York: HarperTorch.

Gold, Thomas B. 1993. "Go With Your Feelings: Hong Kong and Taiwan Popular Culture in Greater China." The China Quarterly 136: 907-925. 
Ho, Wai-Chung. 2000. "The Political Meaning of Hong Kong Popular Music: A Review of Sociopolitical Relations between Hong Kong and the People's Republic of China since the 1980s." Popular Music 19(3): 341-353.

Huang, Hao. 2003. "Voices from Chinese Rock, Past and Present Tense: Social Commentary and Construction of Identity in Yaogun Yinyue, from Tiananmen to the Present." Popular Music and Society 26(2): 183-202.

Jenkins, Henry. 2008. Convergence Culture: Where Old and New Media Collide. New York: New York University Press.

Ji, Jin-Hee (지진희) and Jacky Cheung (Zhang Xueyou 張學友). 2005. “A Melody of Fate," (Mingyun qu 命運曲). 2005. In the album, Perhaps Love: The Movie Soundtrack (Ruguo ai: dianying yuansheng dadie 如果愛電影原聲大碟). Taipei: EMI.

Jian, Weisi (簡偉斯) and Guo Zhendi (郭珍弟), dir. 2004. Viva Tonal! -The Dance Age. (Tiaowu shidai 跳舞時代). Taipei: Taiwan Communications Science Company.

Jones, Andrew F. 1994. "The Politics of Popular Music in Post-Tiananmen China." In Popular Protest and Political Culture in Modern China, eds. Jeffrey N. Wasserstrom and Elizabeth J. Perry, 148-166. San Francisco, CA: Westview Press.

Kaneshiro, Takeshi (Jin Chengwu 金城武) and Zhou Xun (周迅). 2005. "Busy Streets," (Shizi jietou 十字街頭). In the album, Perhaps Love: The Movie Soundtrack (Ruguo ai: dianying yansheng dadie 如果愛電影原聲大碟). Taipei: EMI.

Lee, Joanna Ching-Yun. 1992. "All for Freedom: the Rise of Patriotic/Pro-Democratic Popular Music in Hong Kong in Response to the Chinese Student Movement." In Rockin' the Boat: Mass Music and Mass Movements, ed. Reebee Garofalo, 129-148. Boston, MA: South End Press.

Li, Youyuan (李有源). n.d. “The East is Red,” (Dongfang hong 東方紅).

Liew, Kai Khiun. 2003. "Limited Pidgin-type Patois? Policy, Language, Technology, Identity and the Experience of Canto-pop in Singapore." Popular Music 22(2): 217-233.

Lovesasianfilm. 2006. “Perhaps Love,” (Ruguo Ai 如果愛) Trailer. Uploaded on May 4, 2006. www.youtube.com/watch?time_continue=12\&v=RCIk6j17ewE. Accessed December 10, 2010.

Luhrman, Baz, dir. 2001. Moulin Rouge. Los Angeles, CA: 20th Century Fox.

Moskowitz, Marc L. 2004. "Yang-Sucking She-Demons: Penetration, Fear of Castration, and other Freudian Angst in Modern Chinese Cinema." In The Minor Arts of Daily Life: Popular Culture in Modern Taiwan, eds. Andrew D. Morris David K. Jordan, and Marc L. Moskowitz, 204-217. Honolulu: University of Hawai'i Press.

Moskowitz, Marc L. 2010. Cries of Joy, Songs of Sorrow: Chinese Pop Music and its Cultural Connotations. Honolulu: University of Hawai'i Press.

Na, Ying (那英). 1998a. To Conquer (Zhengfu 征服). Taipei: EMI.

Na, Ying (那英). 1998b. “Meet in 1998,” (Xiang yue 1998 相約一九九八). In the album, To Conquer (Zhengfu 征服). Taipei: EMI.

Park, Chan Wook, dir. 2000. JSA (Joint Security Area). Seoul: C.J. Entertainment.

Tsai, Wen-ting. 2002. "Taiwanese Pop Will Never Die.” Sinorama 27(6): 6-19.

Wong, James. 1997. "Popular Music and Hong Kong Culture." In Asian Music with Special Reference to China and India, ed. Ching-Chih Liu, 95-110. Hong Kong: Music Symposia of 34th ICANAS.

Yang, Mayfair Mei-hui. 1997. "Mass Media and Transnational Subjectivity in Shanghai: Notes on (Re)Cosmopolitanism in a Chinese Metropolis." In Ungrounded Empires: The Cultural Politics of Modern Chinese Transnationalism, eds. Aihwa Ong and Donald Macon Nonini, 287-319. New York: Routledge. 
Zhang, Meijun (張美君). 1997. “A Return Journey to Hong Kong's 1980s Nationalist Sentiment in Pop Music Melodies," (Huigui zhi lu bashi niandai yilai Xianggang liuxing chuzhong de jia guo qing 回歸之旅八十年代以來香港流行曲中的家國情). In The Practice of Affect: Studies in Hong Kong Popular Song Lyrics (Qinggan de shijian: Xianggang liuxing ge yanjiu 情感的實践: 香港流行歌研究), ed. Stephen C.K. Chan (Chen Qingqiao 陳清僑), 45-74. Hong Kong: Oxford University Press.

Zhang, Mingmin (張明敏) ed. 1982. “My Chinese Heart," (Wo de Zhongguo Xin 我的 中國). In the album, My Chinese Heart (Wo de Zhongguo Xin 我的中國心). Hong Kong: Wing Hang Record Trading Company.

Zheng, Jianli (郑建丽), Zhou Tingyu (周婷玉), Wu Xiao'en (吴晓恩). 2004. Garden of Sounds: TV's Spatial Meaning (Huayuan shengyin: MTV de yiyi kongjian 花园声音: MTV 的意义空间). Beijing: Central Compilation Publishing House.

Zhu, Yaowei (朱耀偉). 2000. Glorious Days: Study in Pop Groups in Hong Kong (1984-1990). [Guanghui suiyue: Xianggang liuxing yuedui zuhe yanjiu (1984-1990) 光輝歲月: 香港流行樂隊組合研究 (1984-1990)]. Hong Kong: Huizhi Publishing. 
As noted above, the Uncanny Valley Effect's lack of attention to aesthetic choices needs to be better addressed. Yet we also saw that those in the robotics and animation industries can attest to experiencing consumers' reactions of eerie discomfort when viewing certain images of the uncomfortably close doppelgangers of the living and the lifeless. As with our near fluent speaker, the Uncanny Valley would also seem to be an apt metaphor for ethnic and regional divides between those in the PRC and Taiwan, for example. The unsettling feeling one might have when people confront distorted mirror images - similar yet different in subtle and unsettling ways.

The majority of Taiwan's population is ethnically Chinese and speaks one or more of three Chinese dialects (Mandarin, Hokkien, Hakka) but it has not been under Chinese rule for well over a century. It has also borne tremendous cultural influence from being a Japanese Colony for fifty years (1895-1945) and a strong American influence since then. When Mainland Chinese troops fled the communist revolution to Taiwan between 1947 and 1949, the Taiwanese had been sufficiently influenced by Japan that they found the Mainlanders to be both foreign and uncouth (Morris 2004). Even for the pro-Chinese portion of the population, the initial glee at being reunited with their "homeland" soon gave way to despair. In turn, the Chinese KMT government evinced an intense unease with the Taiwanese whom they felt had become far too Japanese (Morris 2004). The ensuing tensions led to the February 28 massacre of Taiwanese civilians by the newly established Chinese KMT government. The massacre was followed by "the white terror," a period in which those deemed to be aligned with Taiwanese, rather than Chinese, identities were imprisoned or simply disappeared. This mimetic misrecognition of self and other lends insight to some of the continued tensions across the Taiwan straight.

In the PRC, most people see Taiwan as indisputably part of China, conceptually rendering cultural differences to be nothing more than regional identities that one might find in other cities such as Beijing, Shanghai, or Hong Kong. Taiwan's citizens gaze from the opposite side of the looking glass in which they highlight differences in culture and identity from China, proudly calling themselves Taiwanese. This necessitates a constant negotiation of their ethnic heritage and the ways that Taiwan's economy is increasingly becoming inseparable from the PRC. Mimesis is therefore both self-regulatory and an attempt at selfknowledge. The Internet videos that I have presented in this book offer doppelgangers with shared Chinese ancestry a chance to gaze through this mirror reflection of contemporary cultural variance and differing political economies. They reveal cultural proximity that offers shared understandings of humor and visuality, even as they highlight the unsettling differences between the two.

\section{Notes}

1 See bellerbysclip 2016.

2 At the time the video was made, as well as during my interviews, Next Animation Studio's name was NEXT Media. 
3 See E. Yang 2010.

4 This occurred on December 12, 2014 when Next Animation Studio was still called NEXT Media.

5 All of the excerpts from Michael Logan's interview in this chapter took place on July $2,2014$.

6 All of the excerpts from Jessica Wu's interview in this chapter took place on July $2,2014$.

7 See CNBC Videos n.d.; Furness 2016.

8 See Furness 2016; Pearce 2016.

\section{References}

Adamson, Andrew and Vicky Jenson, dir. 2001. Shrek. Los Angeles, CA: DreamWorks Animation.

Adrian, Bonnie. 2003. Framing the Bride: Globalizing Beauty and Romance in Taiwan's Bridal Industry. Berkeley, CA: University of California Press.

BBC News. 2015. “'Forensic Holodeck' Recreates Crimes in 3D," January 28. www.bbc. com/news/technology-30992099. Accessed February 24, 2019.

bellerbysclip. 2016. "Creepy Taiwanese animation Conan \& Andy's violent yoghurt dispute!" Uploaded March 7, 2012. www.youtube.com/watch?v=xwbeXYBEQp4. Accessed August 6, 2016.

Bolter, Jay and Richard Grusin. 2000 [1999]. Remediation: Understanding New Media. Cambridge, MA: The MIT Press.

Burgin, Victor. 2009 [1976]. “Art, Common Sense and Photography.” In Visual Culture: The Reader, eds. Jessica Evans and Stuart Hall, 41-50. Los Angeles, CA: Sage.

CNBC Videos. n.d. " 'Robot goddesses' unveiled in China." CNBC Videos. http://finance. yahoo.com/video/robot-goddesses-unveiled-china-195200014.html. Accessed January $5,2019$.

Dibbell, Julian. 1993. “A Rape in Cyberspace.” The Village Voice 21: 36-42.

Furness, Dylan. 2016. "Chinese scientist built a 'Robot Goddess' then made it subservient and insecure." Yahoo Tech, April 19. www.yahoo.com/tech/chinese-scientists-builtrobot-goddess-215650626.html. Accessed January 5, 2019.

Jenkins, Henry. 2009. "What Happened Before YouTube.” In YouTube: Online Video and Participatory Culture, eds. Jean Burgess and Joshua Green, 109-125. Malden, MA: Polity Press.

MacDorman, Karl F. 2005. "Mortality Salience and the Uncanny Valley." Proceedings of the 5th IEEE-RAS Conference on Humanoid Robots, 399-405.

MacDorman, Karl F., Joseph A. Coram, Chin-Chang Ho, and Himalaya Patel. 2010. "Gender Differences in the Impact of Presentational Factors in Human Character Animation on Decisions in Ethical Dilemmas." Presence 19(3): 213-229.

MacDorman, Karl F., Preethi Srinivas, and Himalaya Patel. 2013. "The Uncanny Valley Does Not Interfere With Level 1 Visual Perspective Taking." Computers in Human Behavior 29: 1671-1685.

Madden, Normandy. 2009. "Q\&A with Next Media's Jimmy Lai.” Advertising Age, July 1. http://adage.com/china/article/china-news/qa-with-next-medias-jimmy-lai/137662/. Accessed May 7, 2015.

Marcus, George. 2012. "Forward." In Ethnography and Virtual Worlds: A Handbook of Method, eds. Tom Boellstorff, Bonnie Nardi, Celia Pearce, and T.L. Taylor, xiii-xvii. Princeton, NJ: Princeton University Press. 
Misselhorn, Catrin. 2009. "Empathy with Inanimate Objects and the Uncanny Valley." Minds \& Machines 19: 345-359.

Mitchell, Wade J., Kevin A. Szerszen Sr., Amy Shiruong Lu, Paul W. Schermerhorn, Matthias Scheutz, and Karl F. MacDorman. 2011. "Short and Sweet: A Mismatch in the Human Realism of Face and Voice Produces an Uncanny Valley." i-Perception 2: 10-12.

Mori, Masahiro. 2012 [1970]. "The Uncanny Valley," Karl F. MacDorman and Norri Kagiki (trans.). http://spectrum.iee.org/automaton/robotics/humanoids/the-uncannyvalley. Accessed April 30, 2015.

Morris, Andrew D. 2004. "Taiwan's History: An Introduction.” In The Minor Arts of Daily Life: Popular Culture in Taiwan, eds. Andrew D. Morris, David K. Jordan, and Marc L. Moskowitz, 3-31. Honolulu: University of Hawai'i Press.

Nakamura, Lisa. 2000. Race in Cyberspace. New York: Routledge.

Nakamura, Lisa. 2002. Cybertypes: Race, Ethnicity, and Identity on the Internet. New York: Routledge.

Nakamura, Lisa. 2007. Digitizing Race: Visual Cultures of the Internet. Minneapolis, MN: University of Minnesota.

Newman, James. 2002. "The Myth of the Ergodic Videogame: Some Thoughts on Player-Character Relationships in Videogames." Game Studies 2(1): online journalno page numbers. www.gamestudies.org/0102/newman/. Accessed January 5, 2019.

Next Animation Studio. n.d. "Next Animation News Direct." www.nextanimationstudio. com/en/newsanimation/. Accessed January 5, 2019.

NEXT Media Tiger Woods. 2009. "NMA 2009.11.29 Animated News Tiger Woods crashes car wife hurt," (NMA 2009.11.29 dong xinwen Tiger Woods zhuanche laopo dashang. NMA 2009.11.29 動新聞 Tiger Woods 撞車被老婆打傷). Uploaded December 2, 2009. www.youtube.com/watch?v=fGfVB9kA5QQ\&feature=youtu.be. Accessed November 3, 2014.

Park, Sung, and Richard Catrambone. 2007. "Social Facilitation Effects of Virtual Humans." Human Factors 49(6): 1054-1060.

Parker, Trey and Matt Stone. 1997. South Park. Los Angeles, CA: Comedy Central.

Pearce, Anthony. 2016. "This Guy Has Spent $£ 35,000$ Building A Robot That Looks Like Scarlett Johansson.” Anthony Pearce's Blog, April 1. www.yahoo.com/tech/this-guyhas-spent-35000-building-a-robot-that-142428505.html. Accessed January 5, 2019.

Rötzer, Florian. 1996. "Re: Photography." Photography After Photography, eds. Hubertus V. Amelunxen, Stefan Iglhaut, and Florian Rötzer, 13-25. Chicago, IL: Art Stock.

Slater, Mel, Angus Antley, Adam Davison, David Swapp, Christoph Guger, Chris Barker, Nancy Pistrang, and Maria V. Sanchez-Vives. 2006. A Virtual Reprise of the Stanley Milgram Obedience Experiments. PLoS One 1(1): e39. http://journals.plos.org/plosone/ article?id=10.1371/journal.pone.0000039. Accessed May 11, 2015.

Spingarn-Koff, Jason, dir. 2010. Life 2.0. Las Vegas, NV: Andrew Lauren Productions.

TIME. 2015. "The 100 Most Influential People: Jimmy Lai." TIME. April 16. http://time. com/3823046/jimmy-lai-2015-time-100/. Accessed May 7, 2015.

Tinwell, Angela, Mark Grimshaw, and Andrew Williams. 2010. "Uncanny Behavior in Survival Horror Games." Games Computing and Creative Technologies 10: 1-38.

Tinwell, Angela, Mark Grimshaw, and Andrew Williams. 2011. "The Uncanny Wall." International Journal of Arts and Technology 4(3): 326-341.

Tinwell, Angela, Mark Grimshaw, and Debbie Abdel-Nabi. 2014. "The Uncanny Valley and Nonverbal Communication in Virtual Characters." In Non Verbal Communication in Virtual Worlds: Understanding and Designing Expressive Characters, eds. 
J. Tanenbaum, S. Seif el-Nasr and M. Nixon, 325-341. Pittsburgh, PA: Carnegie Mellon University Press.

Tronstad, Ragnhild. 2008. "Character Identification in World of Warcraft: The Relationship Between Capacity and Appearance." In Digital Culture, Play, and Identity: A War of Warcraft Reader, eds. Hilde G. Corneliussen and Jill Walker Rettberg, 249-264. Cambridge, MA: The MIT Press.

Vaage, Margrethe Bruun. 2006. "The Empathetic Film Spectator in Analytic Philosophy and Naturalized Phenomenology." Film and Philosophy 10: 21-38.

Yang, Earnie. 2010. "Conan Talk Show: Taiwan animator's revenge (Chinese subtitles)," (kangna tuokou shou: Taiwan donghuashi de fanji (zhongwen zimu) 康納脱口秀: 臺灣 動畫師的反擊 (中文字幕). Uploaded December 8, 2010. www.youtube.com/watch? $\mathrm{v}=$ T5rRPYiTpWM\&list=PLg3SJidgL5_sXF-qGeI7-4n6Oc_JD771G. Accessed June 21, 2013.

Zemeckis, Robert, dir. 2004. The Polar Express. Los Angeles, CA: Castle Rock Entertainment. 